بحوث وבراسات

\title{
الصفات اللعوية المعاصرة للفتوى في العصر الحاضر
}

أ. د. بسيوني نحيلة

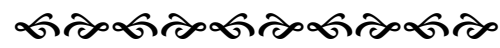

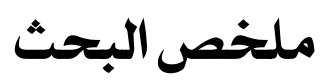

هذا البحث محاولة لدراسة بينية في علم الدعوة وعلم الإفتاء. يحاول الباحث

من خلالما تناول أهم الصفات الدعوية التي يجب أن تتحلى بها الفتوى المعـاصرة مـن أجل تسهيل مهمة الدعوة في وسـط المـدعوين المعـاصرين مـن المسـلمين وغـيرهم. وتهدف الدراسة إلى تأكيد الرابط بين الدعوة والفتيا، وبيان تأثير صناعة الفتوى عسلى عملية نشر الدعوة المعاصرة. ومن خلال المنهج الاستنباطي الذي يجمع بين التحليـل و التعليل، استطاع الباحث الوصول إلى عدة نتائج منها: ضرورة العمل المشـترك بـين الداعية المعاصر والمفتي المتخصص؛ من أجل تحقيق دعوة واقعيـة مـؤثرة، ولصسناعة فتوى عصرية متوازنة. رسالة الإفتاء وثيقة الصلة بحركة الدعوة، خاصة في العصــر الحاضر، فها تقوم به الدعوة من بيان أصول الإسلام ومبادئه، تـأتي الفتـوى فتؤكــهـ، فتكون بذلك وسيلة داعمة من وسائل الدعوة في شرح الصدور وتقريب القلوب إلى

• قسم الدعوة والإعلام كلية الشريعة والدراسات الإسلامية جامعة قطر . البريدالإكتروني:Basyouny@qu.edu.qa 率「人フ 


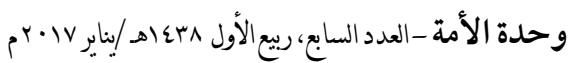

الرسالة، أو تخالفه، فتكون عائقا في حراك الدعوة و مسيرتها، مما يضع الدعوة في دائرة المدافع والمبرر للشبهات، أكثر من كونها بلاغا وإصلاحا. ولهذا يُوصَى: بضرورة عقد الدراسات الأكاديمية التي تربط بين الدعوة الواقعية والفتوى المعاصرة. وغيرها مـن موضوعات العلوم الشرعية، بهدف بلورة علائق عملية منتجة مـن خـالال دراسـات أكاديمية معاصرة.

\section{مقدمَ}

رغم أن الدعوة الإسلامية لا تشترط في دعاتهـا، أن يكونـوا مفتـين. إلا أنهـا

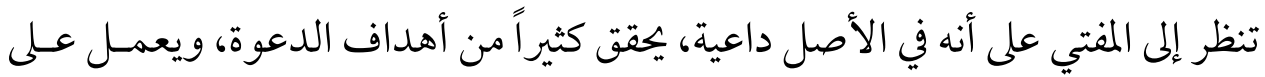
تسهيل مهامها في وسط المسلمين وغير المسلمين. فمن خلال الفتوى، يستشعر الناس

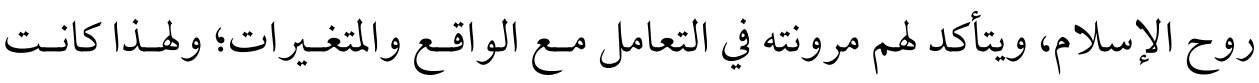
رسالة الإفتاء وثيقة الصلة بحركة الدعوة، وبخاصة في العصر الحاضر، فـما تقـوم بـهـ الدعوة من بيان أصول الإسالام ومبادئه، و الدعوة إلى أخلاقـه وقيمـه، تـأتي الفتـوى فتؤكده، فتكون بذلك وسيلة داعمة من وسائل الـدعوة في شرح الصــدور وتقريسب

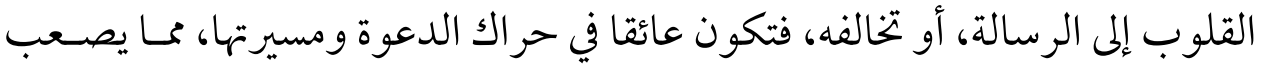

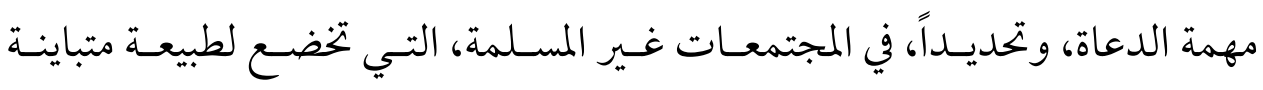
وظروف خاصة، وتحديات متشابكة ومعقدة.

ومن هنا تأتي أهمية هذه الدراسة في بيان أهمية التو اصل بين الفتوى والدعوة،

وضرورة أن تكون الفتيا المعاصرة موسومة ببعض الصفات الدعوية التي تجعلهـا في تقارب وتعاون مع جهود الدعوة المبذولة في العصر الحاضر · بـايساعد عـلى التفاعـل 


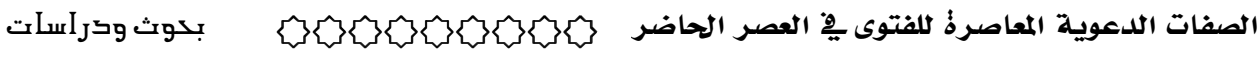

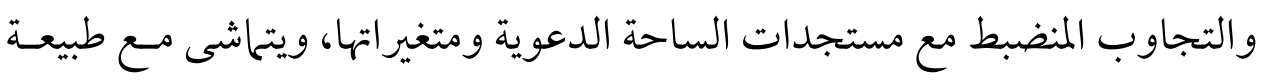
المدعوين و أحو الهم المتنوعة.

تأتي خطة البحث في مقدمة، وثلاثة مباحث، وخاتمة. وبيان ذلك كالآتي:

$$
\text { المبحث الأول: علاقة الدعوة الإسلامية بالفتوى الشرعية. }
$$

المبحث الثاني: الصفات الدعوية اللازمة للفتوى في العصر الحاضر.

المبحث الثالث: الصفات الدعوية المتجددة للفتوى في العصر الحاضر.

$$
\text { الخاتمة: تشتمل على أهم النتائج و التوصيات. }
$$

\section{المبحث الأول :}

\section{العلاقة بين اللهوة الإسلامية والفتوى الشرعية}

يرتبط كل من الدعوة والفتوى ببعضهها ارتباطاً وثيقاً، وذلكك شـأن العلـوم

الشرعية جميعاً، فوحدة المصدر و الهدف و الضو ابط تجمعها، وإن اختلـف مـذاقاها في التنـاول، وتعـددت وسـائلها و أسـاليبها في العـرض و البيـان. وللـدعوة والفتـوى خصو صية في العلاقـة، فمـن خلالهـا يُقــدم الـدين في جانبـه التعليمسي والتطبيقـي، وكلاهما وسيلة فاعلة لتمثيل الإسلام و التعريف بـه في جــالات الحيـاة المختلفـة مـع المسلمين وغير المسلمين. وتتضح هذه العلاقة أكثر مع متابعة أداء الدعوة و الفتوى في كل عصر؛ فالمعروف أن المستجدات والمتغيرات العصــرية تصــع الداعيـة الـواقعي وتعد المفتي المعاصر، وتحدد لهما طبيعة المسار وطـرق السـير فيـه. فالداعيـة والمفتسي، مَعْنيان -على وجه التحديد- بخدمة عصر هما، و وخاطبته بلغة الو اقع؛ ولهذا كـان مـن الضروري أن تلتقي الدعوة مع الفتوى في ججـال الدراسـات الأكاديميـة والمجـالات

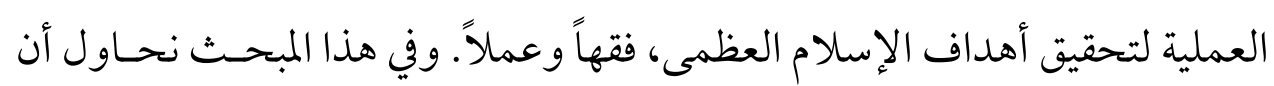




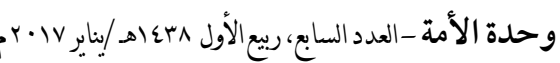
نتطرق إلى طبيعة العلاقة بين الدعوة والفتوى في مجال النظرية و التطبيت، وذلك مـن خلال عنصرين أساسيين: أولاً: العلاقة بين الدعوة والفتوى من خلال المفهوم التخصصي لو تتبعنا تعريف مفهوم الدعوة والفتوى عند المتخصصسين في كـلِ، سـنجد عدة إشارات تدل على التشابه في بعض المهام والتكامل في بعضها الآخر، مما يشير إلى عمق الرابط ووضوح العلاقة بين هذين العِلْمين. ولتوضيح ذلك أبدأ بيــان مفهـوم الدعوة الإسلامية.

فللعلم)ء والمتخصصين في علم الدعوة تعريفات كثيرة و متنوعة، منها: ما هو متعلق بواجب البلاغ ونشر المبادئ(1)، ومنها: ما يمصـر الـدعوة في عمليـة التوجيـه و التعليم. وغيرها(r). و الذي أميل إليه، و أجده متنـاغهاً مـع آيـات الـدعوة في القـرآن

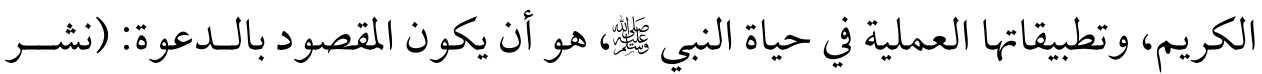
المبادئ بين الناس، وتربيتهم عليها، وتأهيلهم لحملها و الدفاع عنها). ومن خلال هذا التعريف يتبين أن عملية الدعوة تمر بـثلاث مراحسل هـي: (النشر، التربية، التأهيل)، وذلك باعتبار مقصود الرسالة، ومهمة الداعي، وحال المدعو. ولا شك، أن لكل مرحلة من هذه المر احل ما يخصها من مضمون ووسـائل تتطلب لتحقيقها بر امج متنوعة ومتخصصة، يـأتي في مقـدمتها: الإمــدادات الفقهيـة التي تعالج الو اقع والأحداث، والأحكام الشرعية المناسبة للأفر اد والأحــوال؛ ومـن على محفوظ، هداية المرشدين إلى طريق الوعظ والخطابة، (مصـر : دار الاعتصـام، ط9، 9V9 (م)،

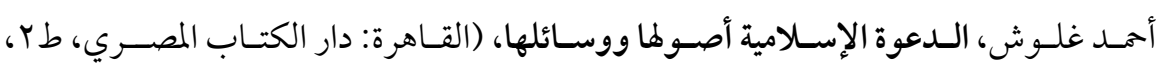




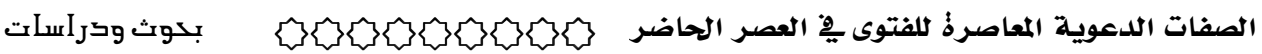
هنا تتجلى أولى العلاقات التكاملية بين الدعوة والإفتاء، و الداعية والمفتسي، وبخاصـة في مرحلة الإعداد والتربية التي هي من أهم مهـام الـدعوة. فالتربيـة تعنـي : التعهـد و البناء، وهذا لا يتحقق إلا على قاعدة مكينة من الأحكام الشرعية وثوابت الإسلام، كما أنها تحتاج إلى تخلية وتحلية، وهذا يتطلب التو جيهات الفقهية الداعمة التي تـرتبط بنصوص الشـريعة ومقاصــهـا وتتعامـل مــع الواقـع والمسـتجدات، وتحصـن مـن

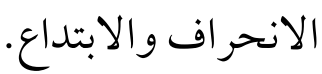
أما عن مفهوم الفتوى -بشكل عـام - فهـو لا يخـرج بعيـداً عـن الـدلالات اللغوية التي يلخصها ما جاء في لسان العرب من أن الفتيا تعني:"تبيـين المشـكل مـن

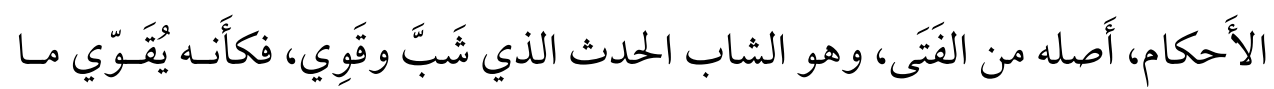

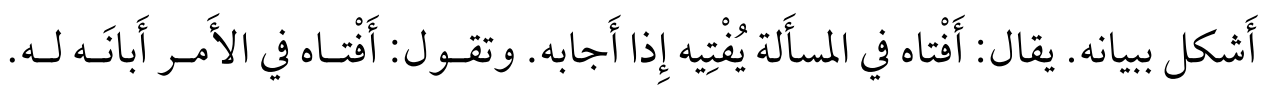

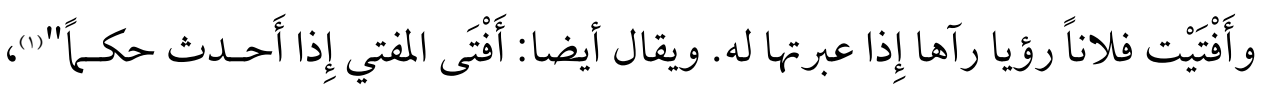
وهذا ما يفهم أيضا من كلام ابـن فــارس إذ يقـول: "إن هنـاك أصـلين للفـاء و التـاء

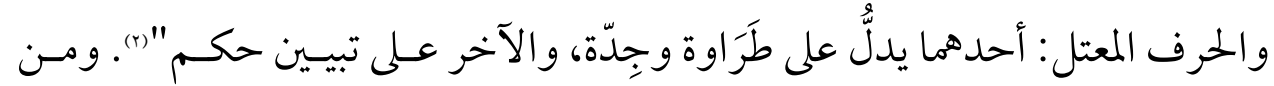
أبرز تعريفات الفتـوى مـا قالـه القـــافي: "الفتـوى إخبـار عــن الله تعـالى في إلـزام أو إباحة" (r). ومن تعاريف المعاصرين قوهم:((الفتوى بيان الحكم الشرعي في قضية مـن

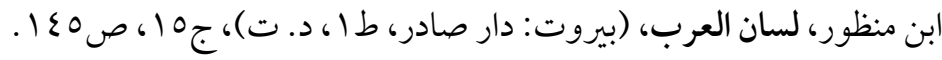

$$
\begin{aligned}
& \text { أحمد بن فارس، معجم مقاييس اللغة، تحقيق: عبد السلام محمد هارون، (بـيروت: دار الفكـر، د. }
\end{aligned}
$$

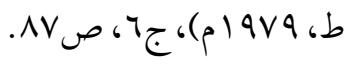

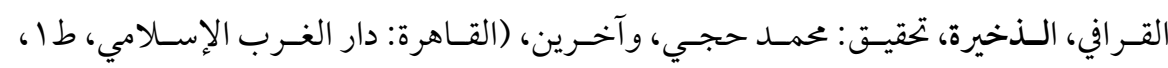

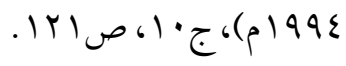


القضايا، جواباً عن سـؤ ال سـائل معـين كـان أو مـبهمم، فــرداً أو جماعـة)(1) وقـوهم:

(الإفتاء: إخبار بحكم الله تعالى عن دليل شرعي، لمن سأل عنه في أمر نازل)(r).

وبالنظر الدقيق إلى هذه المفـاهيم للـدعوة والفتـوى، يمكـن اسـتنباط عـدة

مالمح تبين طبيعة العلاقة ونقاط الالتقاء بين الـدعوة والفتـوى، والـداعي والمفتـي،

و المدعو و المستفتي، وبيان ذلك كالآتي:

الفتوى -بشكل عام - تتعلق بالحكم الشرعي العملي المبني على دليـل. وكـذلك الدعوة تتعلق بالحكم الشرعي في قضايا الإيهان وتبليغه. ولكن في الفتـوى، يـأتي الحكم الشرعي على نية الالتزام و التطبيق من قبل المستفتي غالباً. أما في الـدعوة، فيعرض الحكم الشرعي المتعلق بقضايا التعريـف بالإسـالام عـلى سـبيل التبليـغ الحر، والحوار المتبادل مع المدعو، بهدف إقناعه، والوصول به إلى الهداية والاتباع. تتأسس الفتوى -في الأغلب- بناءً على سؤال سائل من المسـلمين في أمـر محـدد، وقد تكون بياناً عاماً، يحتاج من المفتي الرسمي أن يبادر بها دون سؤال مسـبق أو طلب من معين. أما أصل الدعوة، فهو البيان والإخبار العام الذي يهقـق عمليـة البلاغ، وقد يكون بدون سؤال أو طلب، على سبيل قيام الداعيـة بو اجـب نشــر الدعوة، وبخخاصة مع غير المسلمين. المستفتي: هو المبادر بإنشاء عملية الفتوى في كثير من صورها، وذلك من خـلال سؤ اله الموجه إلى المفتي. وهذه الحالة على عكس ما تتم بـه عمليـة الـدعوة، التـي يو سف القرضاوي، الفتـوى بـين الانضسباط والتسـيب، (القـاهرة: دار الصـحوة القـاهرة، ط ا،

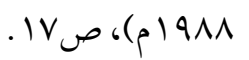

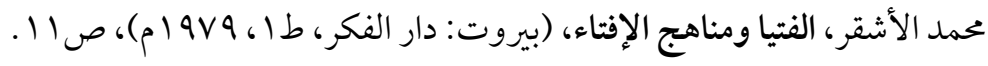




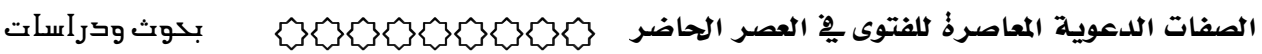
يبادر بها الداعية المدعو في باب الأمر بالمعروف و النهي عـن المنكــر أو الإصـلاح والإرشاد، وذلك في أكثر صورها.

الفتوى: إما في أمر معلوم، يكون عمل المفتي فيه البيان والإخبـار، وهـو في هـذا

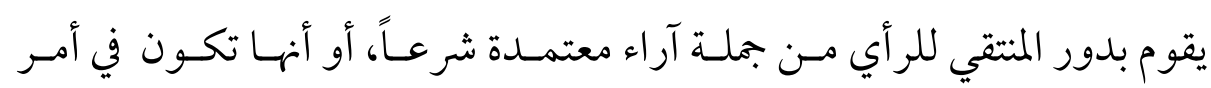

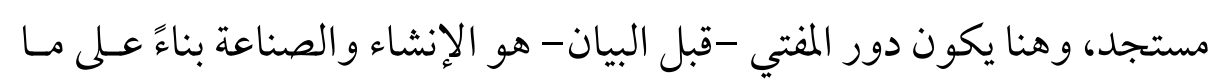
عنده من فقه ومعرفة بالظروف والأحسـو ال في مهنــة إصــدار الفتـوى. والـدعوة كذلك يجب أن تكون في أمر معلوم لدى الداعي فيه من العلم والخبرة مـا يجعلـه ينتقي الأنسب لواقع المدعو وحاله. الفتوى غير ملزمة للمستفتي، فيجوز له أن يختار من جملة الفتاوى التي تقدم لـه، إلا ما كان متعلقاً بو اجب الزمان والمكان، فيا لا يجوز تأخيره عنها، فيلزمه القيام به ما وصله الحكم، وكذلك الدعوة غير ملزمة للمدعو، الذي يجب أن يقتنع قلبه قبل عقله بالرسالة الموجهة إليه، ولكنه يُلـزم بــين يـدي الله تعـالى عنـدما يصـله

$$
\text { البلاغ ويتم معه البيان. }
$$

ثانياً: العلاقة بين الدعوة والفتوى من خلال المفهوم الإجرائي يقصد الباحث بالمفهوم الإجرائي هو التعريـفـ المقـترح للـدمج بـين عمليـة الفتوى والدعوة في التطبيق المعــاصر . وهـو الـــي يـرى المفتـي مـن خلالـه واجـبـ الدعوة، ويرى فيها الداعية موقعه ودوره مع الفتوى في مجال تقديم الإسلام. ويمكن

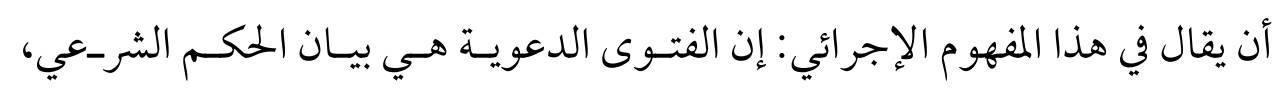

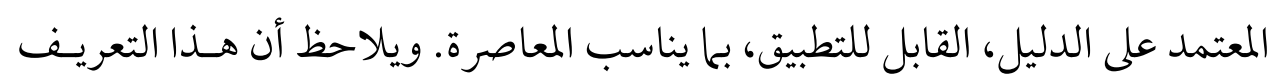
قد جمع بين ما هو شرط في الفتوى وما هو ضرورة في الدعوة؛ وذلك لـيربط بـين دور 
الدعوة والإفتاء، فيما لا يخل بأصول الفتوى، ولا يضر بمهمة الدعوة المعاصرة؛ وعلى هذا تظهر علاقة الدعوة بالفتوى في ججال الملمارسة العملية المعاصرة. وفيها يأتي توضيح ذلك:

(بيان الحلكم) فيه مو افقة للمعنى اللغوي و لما اصطلح عليـه أهـل التخصـص في الفتوى. والبيان: قد يكون بدافع السؤال، أو بدافع الحاجة والضرورة؛ ومن هنـا تتأسس حاسة الدعوة التي تعمل بدافعية ذاتية لتحقيت البيان والـبلاغ الـو اجبين من منظور الشرع، دون طلب أو سؤال.

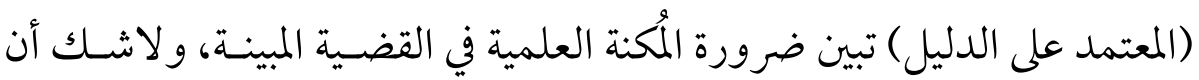

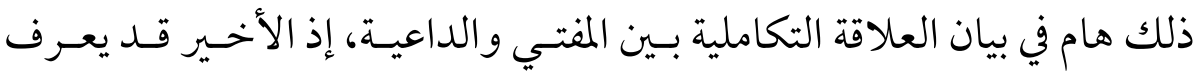
الحلكم، ولا يسعفه تذكر الدليل، في حين أن ذلك لا يقبل فيمن وظيفته الإفتاء. (القابل للتطبيق) فيه مطلب دعوي، يؤكد على مسئولية الإفتاء في إنزال الأحكام على أرض الو اقع ومحاولة تفعيلها في وسـط المسـتفتيين، فليسـت الفتـوى كلامـاً نظرياً مكروراً، إنما لابد أن تكون عين المفتي على ساحة الملمارسة الفعلية، التي هي -في الواقع - محل عمل الداعية الذي من أهم وظائفه: التأكد من توصيل الرسالة إلى المدعو، و إعانته على تطبيقها.

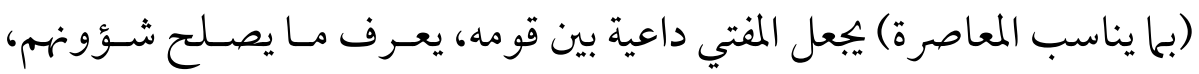
فيقربه لهم، ويجيط بها يتوقع أن يُعْنتهم، فيصرفه عنهم. وأعتقــ أن المفتـي الـذي يُصدر فتوى يصعب تطبيقها، أو التعامل معها، إنها يريد أن ينقل مستفتيه إلى عالم آخر غير الذي يعيش فيه، أو أنه يحاول أن يبعث الحياة فـيما مضسى عصــره مـن اجتهادات، وانتهى أمره من قضايا. 


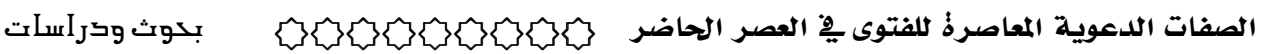
وبعد هذا العرض الموجز لطبيعة العلاقة بين الفتوى والدعوة من ناحية المفهوم العلمي والتطبيقي، يتأكد أهمية أن تكون هناك صفات مشتركة بين الفتوى والدعوة؛ وهذا ما ستركز عليه الدراسة في المبحثين الآتيين. ويرى الباحث تقسيم هذه الصفات إلى قسمين:

الصفات الدعوية اللازمة: والمقصود بها الصفات التي تمثل الجذور والعُمُد التي يقوم عليها البناء، ويمتد معها على مدار الزمان والمكان، فهي صفات مستقرة و مستمرة في أصولها و أشكالها.

الصفات الدعوية المتجددة: وهي التي يمكن تعديلها، بحدوث إضافات عليها، أو بالانتقال إلى غيرها، حسب الوقائع والأحداث المتعلقة بالزمان والمكان. يقول الكفوي: "التغيير: عبارة عن تبديل صفة إلى صفة أخرى، مثل تغيير الأحم إلى الأبيضى. و التغيير إمـا في ذات الشيء أو جـزئسهـ أو الخـارج عنه"(1) . ولأن الدعـوة و الفتـوى من أدوات هـذا الدين المتميز بالثبات في الأصـول والمبادئ، والمرونة في وسائله وتطبيقاته؛ جاءت الصفات على هذين النوعين: اللازم الثابت: الذي لا يمكن أن يتغير أو يتحول مـع مرور الأيام، وتغير الأحوال، بل يجب الحفاظ عليه

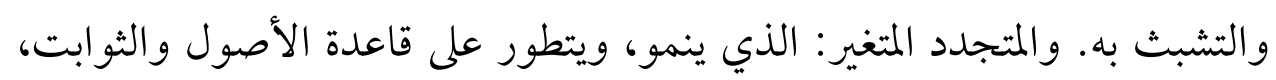
ولربها تدعو الحاجة إلى إنشائه، وفقا لتطورات الأحداث والمستجدات. وبمراعاة هذين النوعين من الصفات معاً، تكون رسالة هذا الدين معبرة عن طبيعته العالمية الشاملة لجميع الأزمان، والأماكن، والأفر اد، كما يؤكد قدرة هذا أحمد الكفوي، معجم الكليات، تحقيق: عدنان درويش، محمد المصري، (بيروت: مؤسسة الرسالة،

$$
\text { د }
$$


الدين على استيعاب قضايا العصر و التعامل معها، من غير اصطدام ولا نكران. وفي المبحثين القادمين نتحدث عن هذين النوعين من الصفات بالشرح و التفصيل إن شاء الله.

\section{المبحث الثاني:}

\section{الصفات اللهوية اللازمة للفتوى في العصر الحاضر}

بينت -فيما سبق - أن الصفات الدعوية المنشودة في الإفتـاء، منهـا: مـا هـو

ثابت مستمر عبر العصور والأزمان، لا يتغير، ولا يتبدل، وذلك فيها يتعلق بالثوابـت

والمرجعية.

وفي هذا المبحث نـحاول أن نتعرف على هـذا النـوع مسن الصـفات اللازمـة؛

وذلك لتحقيق عدة فوائد، منها:

ا - بيان عمق الرابط بين الفتوى والدعوة على مدار التاريخ، وأن الفتوى لا يمكن ها

أن تكون في معزل عـن سـاحة الـدعوة المعـاصرة، كـا أن الـدعوة لا يمكـن أن

تستكمل مسيرتها الإصلاحية بدون هيئات الفتوى ومؤسساتها.

Y - التأكيد على ضرورة التحلي بهذه الصفات عند صناعة الفتـوى، وأثنـاء تقــيمها، وذلك من أجل التنسيق والتآزر بين فروع التخصصات الشــرعية، وبخاصسة في مجال الدعوة العملية. وفيما يأتي عرض ببيان أهم هذه الصفات. أولاً: إلهية المرجعية

الدعوة الإسلامية إلهية في الغاية والمصدر. فالتوجه فيها لله وحسده، وهـدفها دعوة الناس إليه. و مصدرها هو كتابه الـذي أنـزل عـلى رسـوله الخـاتم. وهـذا هـو الأصل الأصيل الذي يجتمع عليه كل من الفتوى والدعوة، فكلاهما ينـال مصـداقيته 


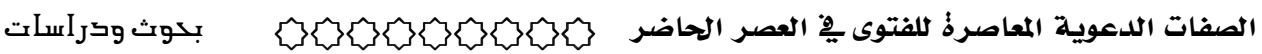
في الاعتحاد الكامل على معيار القرآن والســنة. و الغايـة في كلسيها هـي إرضـاء مُنــِّل القر آن و السنة (الله سبحانه وتعالى) . وهذا ما نقصده بإلهية المرجعيـة، كصـفة دعويـة ثابتة للفتوى المعاصرة؛ وتتحقـق هـذه الصـفة مـن خــلال تحديـــ ركـائز البـدايات، ووضوح مقاصد النهايات، فإن كانت البداية (المصدر) و النهاية (الغاية) إلهيـة كانـت المرجعية إلهية.

وتأتي أهمية هذه الصفة في الفتوى، في كونها تبرز روح الإسلام وفاعليته مـع

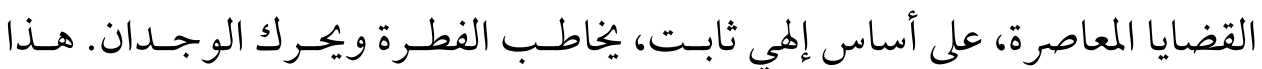
بالإضافة إلى أن إبراز موضوع المرجعية الدينية على مسـتوى صـناعة الفتـوى، ومسن خلال تقديمها، يُعد من أقوى الوسائل الدعويـة المبـاشرة التـي تحـــك عقـل المـدعو وتدفعه للتفكير، وتحثه على المقارنة بين دعوة الإسلام، ويرجع ذلك لسبيين: الحديث عن المرجعية الدينية -بشكل عام - يمثل موضو عاً أساسياً عند كثير مسن المدعوين، وبخاصة عند مرحلة التعريف بالإسالام مع غير المسـلمين؛ فالمرجعيـة

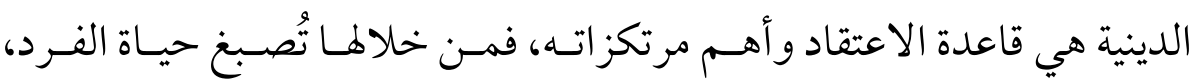
وتنتظم ججرياتها، ويوضع مسارها، فإن كانت مرتبطة بالقدرة الإلهية الخالقة كـان

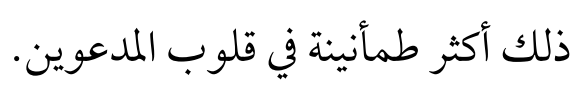
مـا تشـهده ســاحة الأديـان العالميـة المعـاصرة مــن تعـدد المرجعيـات الدينيـة واضطر ابها، فهناك من يتخذ عقول البشر مرجعية، بدعوى النيابة عن الله، أو من

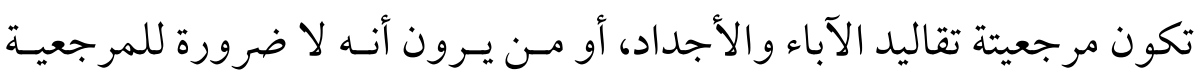
الدينية في حياتهم أصلا، إنها يعتمدون على أعحال القلوب والأرواح.

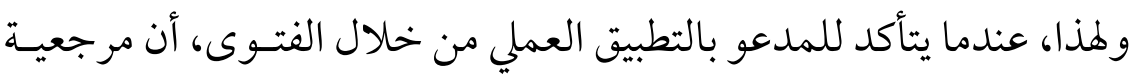
الإسلام المعتمدة في استصدار الأحكام واستنباط الفتاوى الشـرعية الضـابطة لحيـاة 
الأفر اد والمجتمعات، هي الإلهية في المقصد والمصدر، وليس المفتي فيها إلا مبلغاً عـن

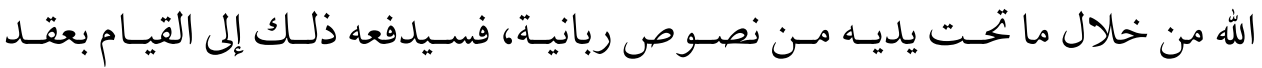
مقارنات عقلية، تمهد لقناعات تتقارب مع نداء الفطـرة، فتعـين عـلى تسـهيل مهمــة

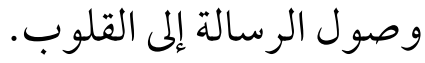

ومن أهم المعاني الدعويـة التـي تعـين هـذه الصـفة عـلى إبرازهـا في عقـول المدعوين وقلوبهم، ما يأتي: الحفظ الدائم المستمر لرسالة الدعوة من التحريف أو الانحـــاف، أو الانخــاع بالمؤثرات، وذلك لثبات المرجعية وعد تأثر ها بأهو اءونزوات البشر. قدسية وتشريف الأحكام و الفتاوى، فهي محاطة بسياج الربانية بدءاً وانتهاءً، وأن عمل البشر فيها لا يخرج عن قو اعد هذه الربانية وضو ابطها.

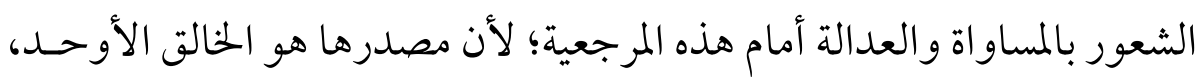
وهي لخلقه جميعا. الثقة و الطمأنينة لأحكام هذه الرسالة، التي لا عمل للبشر فيها إلا الإخبـار عـن الله و التوقيع عنه سبحانه. ولربها كان هذا البعد الدعوي في مرجعية الفتـوى هـو أحسد الأسـبـاب وراء اهتحام علم)ء الإسلام بالتأكيد على صفة الإلهية في المرجعية وإثباتها للفتوى والمفتي، في

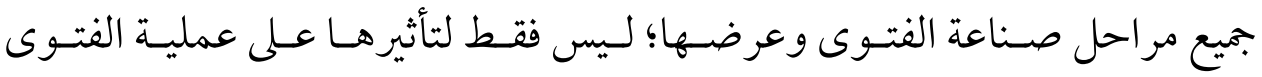
ومصداقيتها في قلوب المستفتيين، إنها أيضا لتأثيرهـا عـلى مظهـر الإسـالام في قلـوب المدعوين. من ذلك ما ذكره ابن حمدان الحنبلي"(). أن المفتسي لا يعـدو دوره في صسناعة أحمد الحراني، الفتوى والمفتي والمستفتي، تخريج: ناصر الدين الألباني، (دمشق: منشورات المكتب

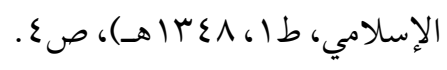




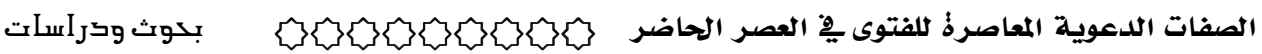
الفتوى إلا أن يكون مخبراً عن الله تعالى بحكمه. كما اعتبر ابن الصلاح المفتـي موقعـاً

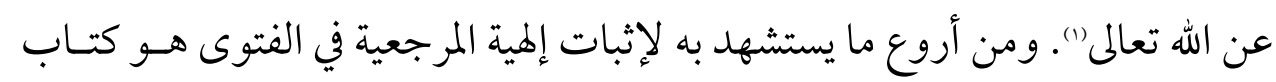
ابن القيم حول موضوع الفتوى، فقد عنونه بإعلام المـوقعين عـن رب العـالمين، وفي ذلك إشارة إلى أن المفتي في موقع من يوقع عند الفتوى بخاتم رب العالمين. يقول ابن القيم:"أول من وقع عن الله هو الرسول-

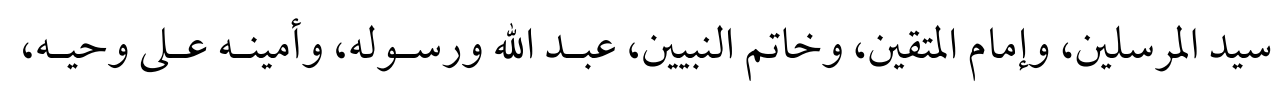
وسفيره بينه وبين عباده؛ فكان يفتي عن الله بوحيه المبين،"((). ثانياً: صناعة الفتوى على هدف الدعوة

للدعوة الإسلامية أهداف، قامت مـن أجـل تحقيقهـا، وتحرّكَ الـدعاة عـلى

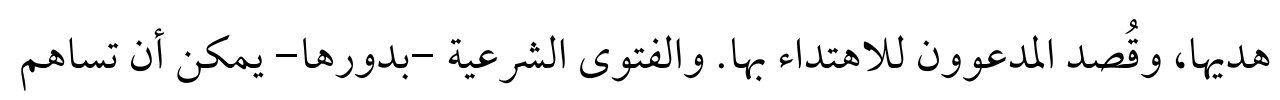
-بشكل مباشر - في تحقيق أهداف الدعوة في محيط المدعوين، وهذا ما يجـبـ أن يُقـنـن

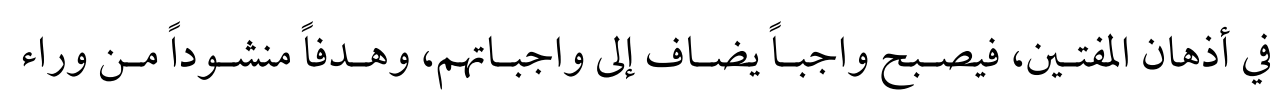
جهودهم، وصفة لازمة لجميع فتواهم. فتنتقل من الحديث العارض العام إلى الهـف القاصد. ومن أهم أهداف الدعوة الإسلامية التي يجـب أن تهـتم الفتـوى بإبرازهـا: هدف إرشاد الناس إلى مصدر حياتهم ووجودهم، وذلك عن طريق إمداد المسـتفتيين (المدعوين) بالإجابات الصـريحة الصـحيحة و الحقــائق الصـادقة لكـل مـا يـدور في

$$
\begin{aligned}
& \text { ابن الصلاح، فتاوى ومسائل ابن الصلاح ومعه أدب المفتي والمستفتي، تحقيق: عبــ المعطي أمـين }
\end{aligned}
$$

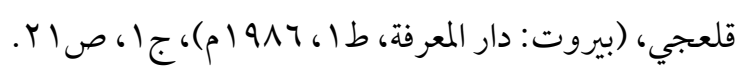

$$
\begin{aligned}
& \text { ابن قيم، إعلام الموقعين عن رب العالمين، تحقيق: أبو عبيدة مشهور آل سلمان، (السعودية: دار ابن }
\end{aligned}
$$

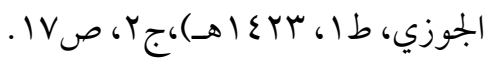


خلجهم من أسئلة واستفسارات عن مصدر حياتهم، و منشئهم، و معـادهم، وغيرهـا من الأمور التي إن وضـحت في قلـب وعقـل كـل إنسـان صـفت فطرته،، وهـدأت سريرته، واستقر باطنه وظاهره. والمفتي فيما يقوم به مـن دور الإفتـاء، ربـا يتعـرض لأسئلة مباشرة عن الخالق والخلق، و من هنا يسـتطيع أن يحقـق هــذا الهـدف بطريقـة مباشرة في جو هادئ طبيعي. وربها يتناول هذا المدف بطريقـة غـير مبـاشرة مـع كـل سؤال يُعرض عليه، وذلك من باب التمهيد والمقدمة الضــرورية عـن (الله سـبحانه وتعالى) المشرع، الذي يعتمد عليه المفتي في استخلاص الأحكام و التشريعات. ويمكن أن يحقق المفتي هذه الصفة مـن خـالال مراعاتـه وتركيـزه -المبـاشر وغير المباشر - على بعض الأمور الآتية عند صياغة الفتوى وتقديمها: الحديث عن الخالق بيــان صـفاته العظمسى وأسـائه الحســى كـالحي والمحيـي، و الرب والرزاق، فذلك مما يشـيع في الـنفس الرغبـة مــح الرهبـة، والخـوف مـح الرجاء؛ بها يحقق التوازن الروحي، والاعتدال الفكري. التأكيد على أن الكون مسخر لمصـلحة بنـي الإنســان، فكـل مــا فيـه موجـه إليـهـ وخلوق من أجله، الليل، النهار، الأرض، السماء، الطيبات. وغيرها. فلاشك أن النفس البشرية تميل وتلين إلى من يفكر فيها، ويعمل لنفعها. نسبة المخلوق إلى خالقه (كنحـو قولـه: ربـك، ربكــم، خالقـك، إلهـك. ) يشـعر بالخصو صية و التكريم، و يبعث في النفس الثقة وتقدير الذات. وبالنظر إلى كثير من الفتاوى المعاصرة، نجد أن بعضاً منها يتحدث، أو يشـير إلى بعض هذه المفاهيم، عند مطلع الفتوى أو ختامها، ولكن ما يريــد الباحـث إثباتـه و التأكيد عليه هنا، هو أن تصبح هذه الأقـو ال مـن الصـفات الثابتـة للإفتـاء، حيـث 


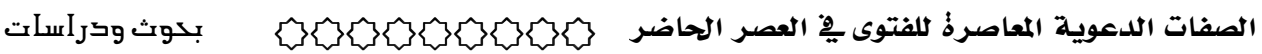
تتعدى نطاق الروتينية الجافة، لتكون سمتاً عاماً متجدد الروح، ليس فقط في عبارات تقليدية ثابتة مُتَضَمنة مع محتوى الفتوى، إنها يجب أن تكون مراعية لطبيعة الفتوى وما يو افق سائلها. و لاشك أن تحقق ذلك على سبيل أنه صفة ثابتة يساعد على تحقيـق المشـاركة

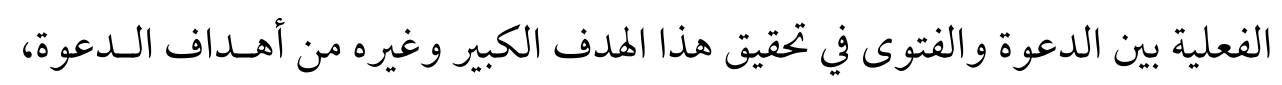
كما يكون دعهاً للداعية والمدعو على السواء، فالأول بتسهيل مهمته في البلاغ و البيـان. و الثاني في تقوية استعداداته الفطرية، وتحفيز ملكاته العقلية. ثالثاً: الكفاءة والأهلية أساس القيام بالفتوى المفتي: هو القائم بأمر الفتوى، وله في الإسلام منزلة خاصة ومكانة متميـزة،

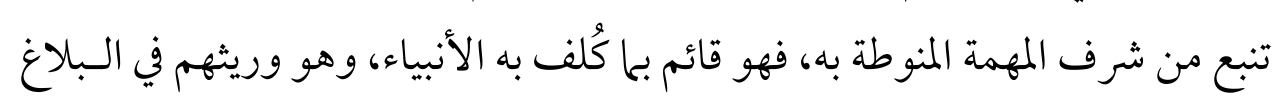

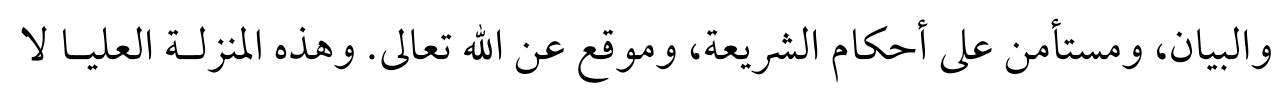
تنال بالتمني و المحاباة، ولا بالور اثة و المجاملة. إنها معيار الرفعة والتميز في هذا الأمـر

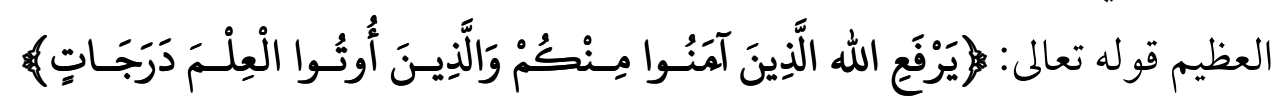

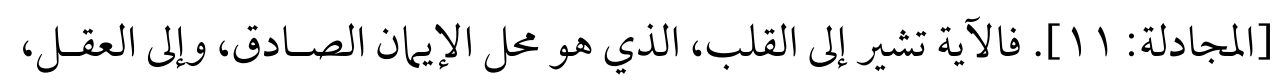
الذي هو محل العلم النافع. والمفتي في الإسالام، لابد أن يجمع - إجمالاً- الأمرين معا: صفاء القلب وخلو صه بالإيهان ومتطلباته، وقوة العقل وتمكنه مـن العلـم وأدواتـه. وهذه هي معايير صفة الكفاءة في الإفتاء الدعوي، وبالأمرين معا يتميز المفتي في أدائه للفتوى، فلن تكون فتو اه نتاج علمٍ جافٍ إنـا سـتجمع معهـا الإيـان الـذي يضـبط مسارها، وينفث فيها روح التفاعل والقبول؛ بها يوسع أثرها ويزهر ثمرتها. وإلى نحو

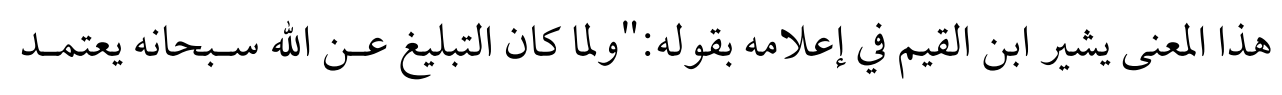

$$
\text { (r.... }
$$


العلم بها يبلغ، والصدق فيه، لم تصلح مرتبة التبليغ بالروايـة و الفتيـا إلا لمـن اتصـف بالعلم و الصدق؛ فيكون عالماً بـا يبلغ، صادقاً فيه، ويكون مع ذلـك حسـن الطريقـة، مرضي السيرة، عدلاً في أقو اله و أفعاله، متشابه الســـر و العلانيــة في مدخلـه وخخرجـهـ و أحو اله؛ وإذا كان منصب التوقيع عن الملوك بالمحل الذي لا ينكر فضله، و لا يجهـل قدره، وهو من أعلى المراتب الســيات، فكيـف بمنصـب التوقيـع عـن رب الأرض و السموات؟ فحقيق بمن أقيم في هذا المنصب أن يعد له عدته، وأن يتأهب له أهبته، أحسك وأن يعلم قدر المقام الذي أقيم فيه، ولا يكون في صدره حرج من قول الحق والصدع به؛ فإن الله ناصره وهاديه"(1). ومن الجحدير بالذكر أن نشـير هنـا إلى أن مـن علامـات الإيهان الصادق مع العلم الو افر: أن يتورع الفرد عن طلب الفتيا لنفسـه، بـل يهـاول الفرار منها لعظيم أمرها، و جليل قدرها، إلا إذا كان بتعيين الثقات له، فيقبلهـا قيامـاً بالواجب الشرعي. وأمثلة ذلك كثرة في تاريخ المفتين. من أشهرها ما نقل عن الإمام مالك في قوله:"ما أفتيت حتى شهد لي سبعون أني أهل لـذلك". وقولـه: "لا ينبغي لرجل أن يرى نفسه أهلا لشيء حتى يسأل من هو أعلم منه"(r). ولا يخفى أثر هذه الصفة في الفتوى على الدعوة المعاصرة، فمثل هذه المعايير القائمة على تقوى الله و العلم معاً مما يفقده الباحثون عن الدين الحق بــن الأديـان في

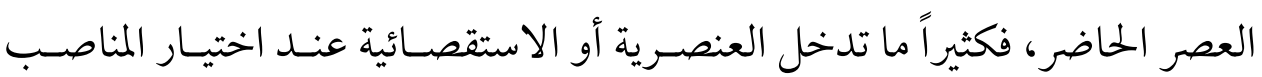

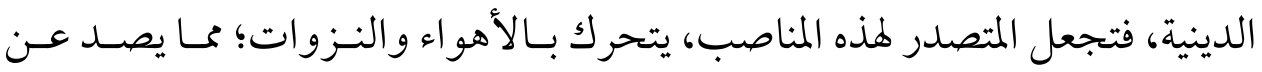

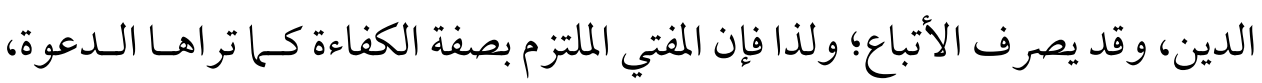

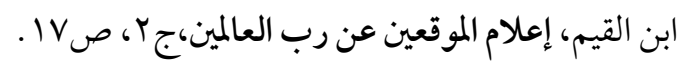

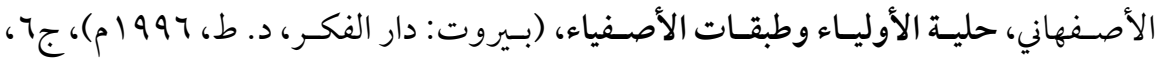

$$
\text { 多变 }
$$

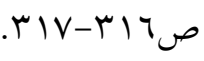




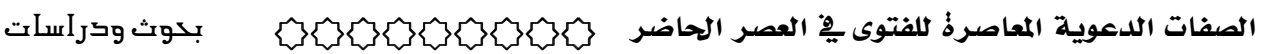
يساهم كثيراً في تقوية انتماء الأتباع لدعوة الإسلام والاعتزاز بها، كما أنه يكون عنصـر

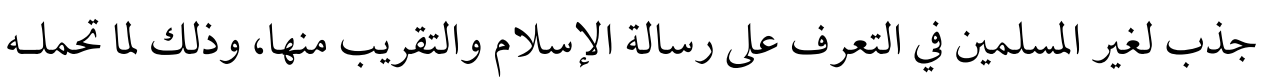
هذه الصفة من معان ورسائل دعوية مؤثرة في قلوب المدعوين. منها على سبيل المثـال ما يأتي: بيـان أن مناصـب الـدين في الإســام مكتسـبة وفـق الكفــاءة العلميـة، والقـوة الروحانية، إلا النبوة فقط، فهي هبة الله لمن يشاء من خلقه. وعلى هذا يمكن لكل من توفرت فيه المؤهلات و الصفات -السابت ذكرها - أن يكون مفتياً، دون النظر إلى عرقه أو مو طنه، أو جنسه، فلا فضل إلا بالعلم و التقوى. اجتماع الخُلق والإيحان مع العلم والمعرفة في اختيار الموقعين عن الله، يضـفي عسلى الفتوى صبغة روحانية وطاقة إيهانية، تبعث على الحركة و الفاعلية في أقو ال المفتي عند القيام بو اجبه، مما يكتب له القبول عند الناس. إن تحقق كفاءة المفتي في قوة إيـانه مع العلم، يؤهله لأن يكــون قـدوة عمليـة بــنـ المدعوين، الذين يأسرهم الفعل أكثر من القول.

رابعاً: تقدير المسئولية المشتركة بين أطراف الفتوى المعروف أن الفتوى مسؤولية كبيرة، ولكن ربها يُحمِّل البعض المفتي فيها قدراً كبيراً، وآخرون قد يحملون المستفتي فيها القدر الأكبر، ويرى الباحث أنه لابد من أن تقوم الفتوى على المسؤولية المركبة، التي يستشعر فيها الطرفان المسؤولية عن صسناعة الفتوى السليمة المناسبة في المسألة المعنية. فالمستفتي مطالب أن يسأل إذا لم يعلم، وأن يسـأل الأعلـم و الأصـلح، وأن يظهر مسألته بلا غموض أو إلباس، وأن يجيب المفتي بوضوح وصدق عما يوجه إليـه 移 


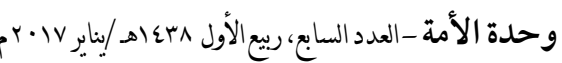

من استفسارات حول القضية، و أن يتأكد من فهم مضـمون الحـكـم وإجر اءاتـه، وأن يعزم على قبول الحكم و الالتزام به. و المفتي مسؤول عن تمكين المسـتفتي مـن السـؤ ال، واسـتجماع كـل أطــراف

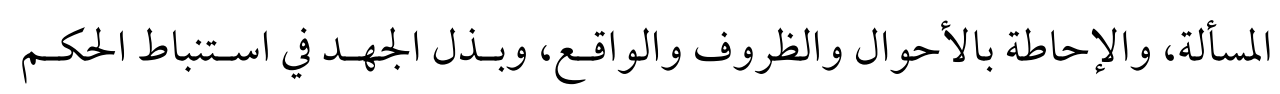
الشرعي الأيسر، وأن يعين المستفتي على التطبيق والتنفيذ. وغير ذلك. واستشعار كلٍ من المستفتي والمفتي لعظم هذه المسئولية، يرفع من قدرها، ويساعد على الوصـول إلى

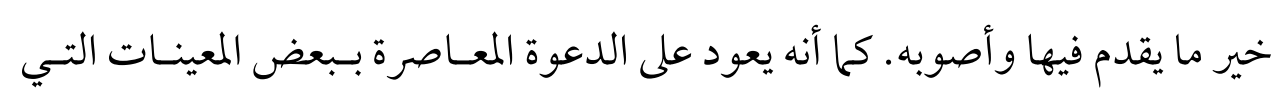
تدعم رسالة الإسلام في قلوب مدعويها، وتميزها بين الدعوات بمفاهيم ومعان تدفع إلى التفكير والتقدير في عين المراقبين. من هذه المفاهيم ما يأتي:

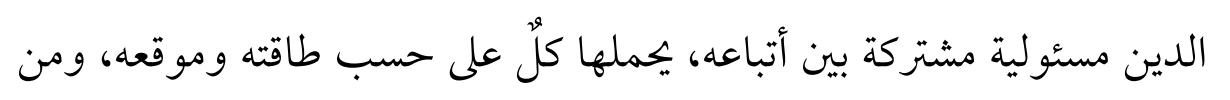

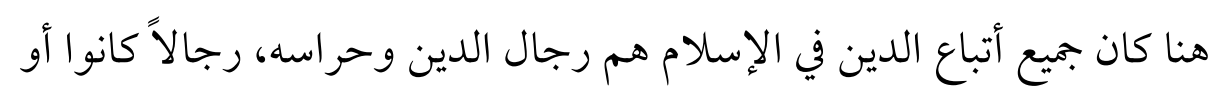
نساءً، كباراًانوا أم صغاراً، وليس كما تدعي بعض الدياع الديانات أن للدين رجالاً غير الرجال، أو أن الرجال طبقات في الدين. الوضوح والشفافية والمؤازرة والمؤاخاة بين علم)ء الدين وعامة الأتباع، في القيام بواجبات الدين، وتحقيق التكليفات، دون تميز إلا بأداء الو اجب و القيام بالمسؤولية. الاشتراك في المسئولية يعني: الاشتراك في الأجر، كما يقتضي التحمل في الوزر،

$$
\text { ولا يحمل في ذلك أحدِ عن أحٍِ شيئا. }
$$

خامساً: الدقة في صناعة الفتوى والحذر الثديد من الإخلال بشروطها هذه الصفة دليل تقوى الله وخافته، وهي تتحقق بالمراجعة الدائمة والمبـادرة بتصحيح الخطأ، دون مواراة أو حرج. فبالمراجعة يُطور الأداء إذا كان حسناً، ويُعـدل

$$
\text { 药 }
$$




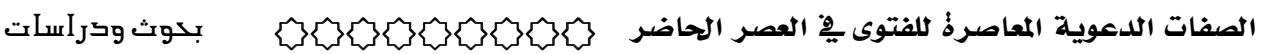

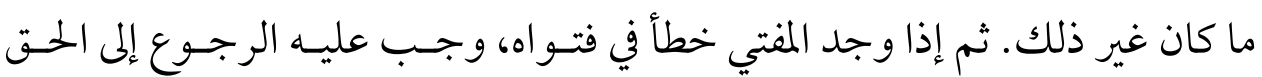
و الاعتر اف بالخطأ، دون تردد، فهذا مما يزيـد مـن قـدره، ويرفـع مـن مهابـة الحكـم الشرعي، وينمي الثقة و الطمأنينة في قلوب المستفتيين، ويؤكد ربانية المرجعيـة. يقـول القرضاوي في حديثه عن الجانب الأخلاقي للمفتي: "وأن يرجع عن الخطـأ إذا تبـين له، فالرجوع إلى الحق خير له من الـتمادي في الباطلـ، ولا إثـم عليـه في خطئه؛ لأنـه

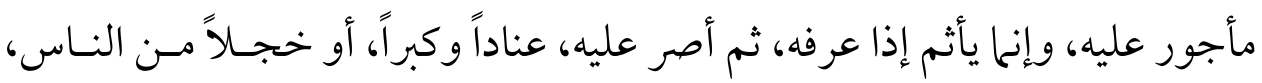
و الله لا يستحي من الحتق" (1).

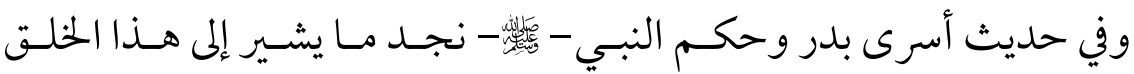

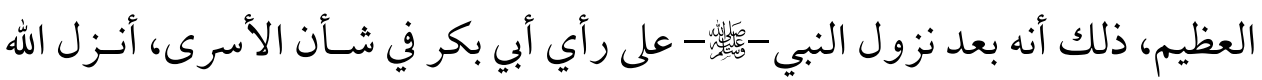
قرآناً، يعاتبه في هذا الحكم، ويبين له الحكم الأنسب في هذه الحالة، فلما وضـح الأمسر

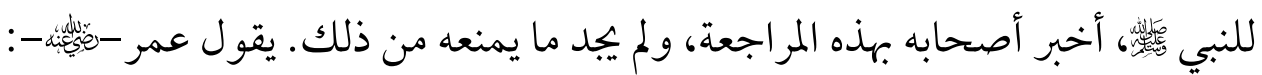
"فلما أن كان من الغد، غدوت إلى النبي هما يبكيان. فقلت: يا رسول الله، أخبرني ماذا يبكيك أنت و صاحبك فـ فـإن وجـدت بكاءً بكيت، وإن لم أجد بكاءً تباكيت لبكائكما. قال: فقال النبي علي أصحابك من الفداء، لقد عرض علي عذابكم أدنى مـن هـذه الشــرة، لشـجرة

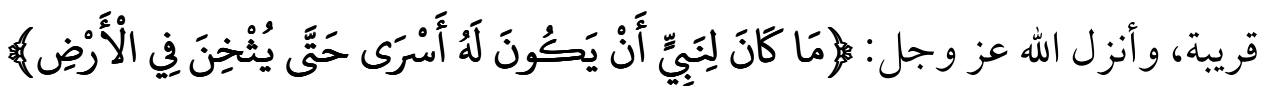

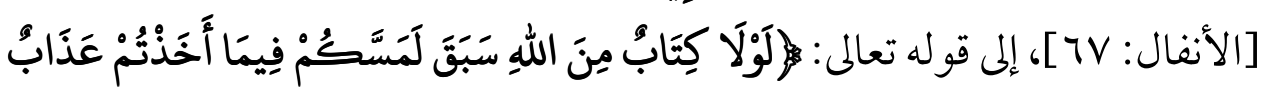

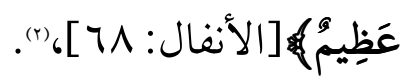

$$
\text { القرضاوي، الفتوى بين الانضباط والتسيب، صع ع. }
$$

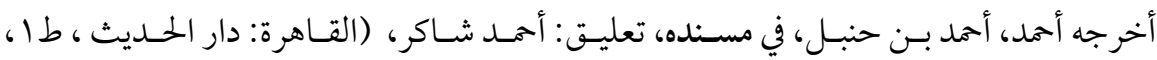

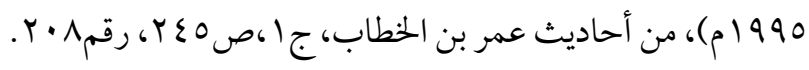

$$
\text { 级 }
$$




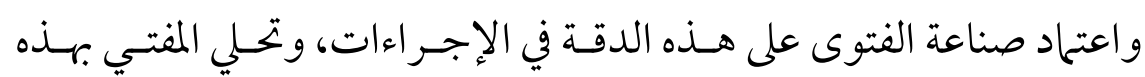

الصفة من الحذر، يبعث بعدة رسائل دعوية تعود بالأثر الإيجابي عسلى حركـة الـدعوة بشكل عام. من هذه الرسائل ما يأتي:

بيان أن منزلة أحكام الإسلام وتشريعاته فوق الأفر اد، دون اعتبار اتٍِ، مها كـان

شأنهم.

المرجعية العليا في الأحكام هي الفيصل في تقييمها والحكم عليهـا، وأن مرضـاة

$$
\text { الله هي الغاية التي ترتجى. }
$$

صلاح أمر المستفتي وهدايته إلى الأصوب في المسألة هي أساس مهمة الإفتاء. ولاشك أن وضوح ذلك في عين المتابعين من المدعوين يعيـنهم عـلى التميـز بين دين يصنعه البشر، وتديره الأهو اء، ودين يتحرك فيه البشر من أجل إرضاء رب البشر.

سادساً: التجرد وعدم التأثر بالهيئات والمنظمات

يجب أن يكون الإفتاء مستقلاً، بعيـداً عـن المـؤثرات المجتمعيـة والسياسـية؛

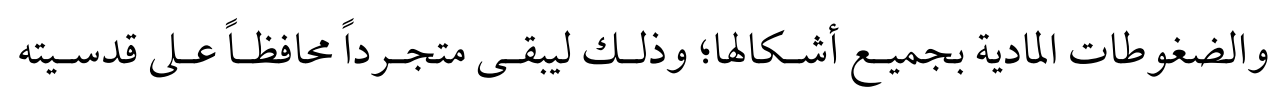
ومهابته. وتُعد هذه الصفة من أبرز الأدلة على صدق ما سبق من صـفات. وخـير مـا يذكر للبيان والاستدلال لذذه الصفة ما قاله النبي في سرقة المرأة المخزومية، فلقد جاءه المستشفعون لتغيير الحكم أو رفع العقوبة، فكان

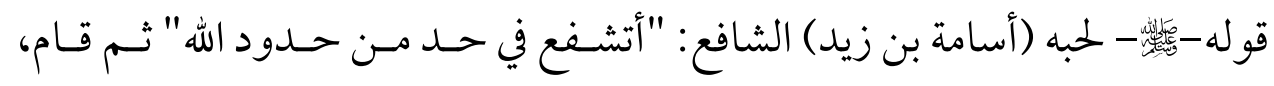
فاختطب، ثم قال: "إنها أهلك الذين قـبلكم، أنهـم كـانو إذا سرق فــهم الشــريف تركوه، وإذا سرق فيهم الضعيف، أقامو اعليه الحد. وأيم الله، لو أن فاطمة بنت محمد 


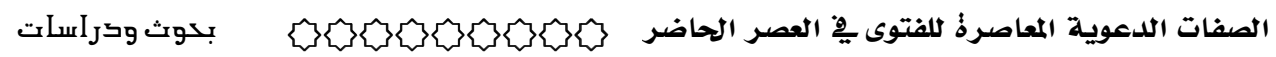

(1)." سرقت لقطعت يدها

هذا هو التجرد الذي نعينه في هذا المقام، أن يقطع القائم بـالفتوى وإصـدار

الحكىم عند البيان و الصدع به كل علاقة إلا علاقته مع الله تعالى المشرّع، الـذي ينـوب

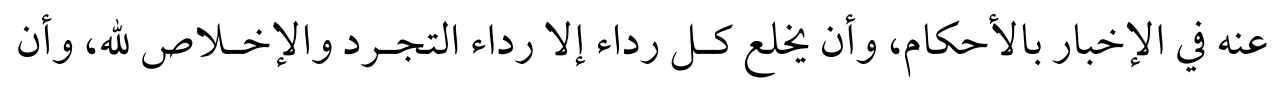
يسمو في مقام البيان فوق حظوظ النفس وضغوط الهوى وشفاعة الوجهاء. وباتباع المفتي لفذه الصفة في تعاملاته، وشيوع ذلـك بـين جمـاهير المسـلمين، يجتمع حوله المخلصون المنصفون، وينسحب من مجالسـه أصسحاب النو ايـا المريضسة والأهو اء السقيمة، ويبعث الطمأنينة في قلوب العامة والضعفاء. أما إذا ارتضى المفتي

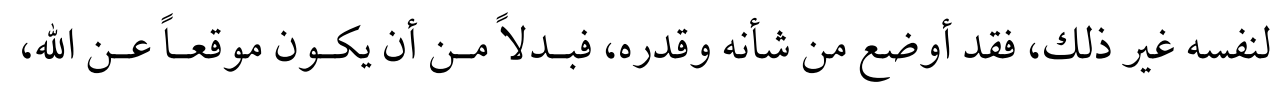

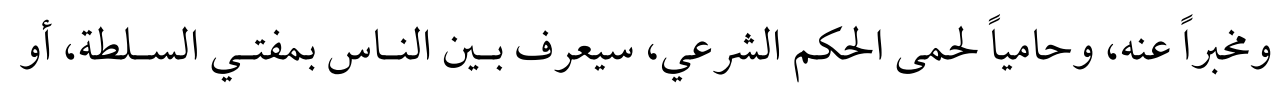

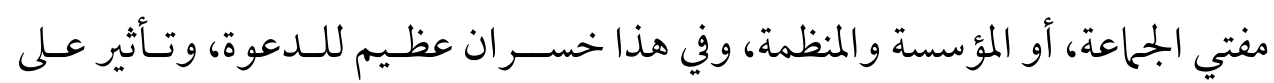

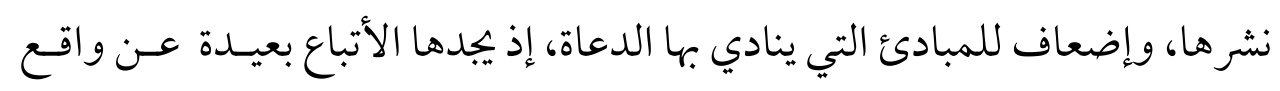
رموز الرسالة، وملة مناصبها.

هذه هي بعض الصفات التي تراها الدعوة لازمـة في الفتـوى بشـكل عـام، وبخاصة في العصر الحاضر، ويعتقد الباحث أن اهتمام الفتوى بهذه الصـفات، وتحسلي

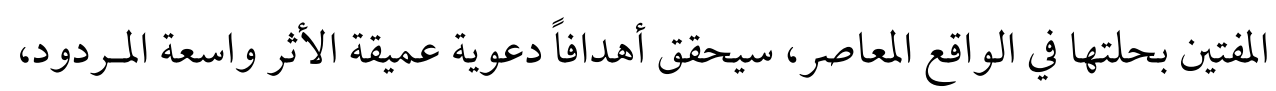
ربها أكثر من أحاديث كثير من الدعاة وخطبهم، وتحديداً في وسط شرائح المـدعوين الدارسين للإِسلام و المتابعين لحركة أفر اده ومؤسساته الدينية وغيرها.

أخرجه مسلم، مسلم بن الحجاج، في صحيحه، تحقيق: محمد فؤاد عبد الباقي، (بيروت، دار إحياء

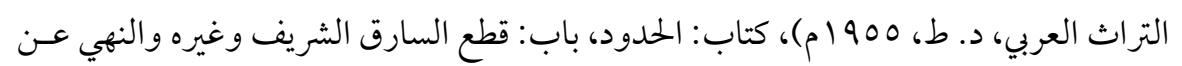

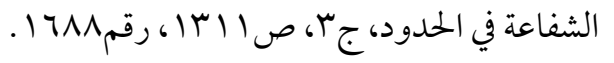
繁算 
ويجدر أن أشير إلى أن ما ذكر من صفات يمكن أن يندرج تحته صـفات أخــر

فرعية، تعمل نفس التأثير فيمن حولها. و المطلوب أن ينتبه المفتي في ساحة الفتـوى إلى دوره الدعوي، وواجبه تجاه دعم الرسالة ونشر مبادئها، بالإضافة إلى ما يقوم بـه مسن بيان أحكامها وتشريعاتها.

\section{المبحث الثالث:}

\section{الصفات اللعوية المتجلدة للفتوى في العصر الحاضر}

بينت في المبحث السابق بعـض الصـفات الدعويـة التـي يهـب أن تصـحب

الفتوى بشكل لازم حيث دار الزمان والمكان. وفي هذا المبحث نشير إلى أهم الصفات الدعوية التي تقبـل التطـوير والتحســن، وفقـاً للمسـتجدات و الإمكانـات، وتبعـاً للظروف والأحو ال، بهدف رفع مستوى أداء الفتـوى المعـاصرة مـن حيـث الشـكل وسبل العرض بها يخدم الدعوة، ويعين على نشرها. وعدّ الباحث هذه الصـفات مـن

$$
\text { النوع المتجدد المتغير لعدة أسباب. منها: }
$$

قابليتها لاختلاف طرق التعامل معها من ناحية تناولها وتطبيقها من فرد إلى فرد،

ومن موقف إلى موقف، ومن زمان إلى زمان.

لفتح باب تطويرها وتحسين طرق أدائها، حسب مستجدات العصر، بها يصب في مصلحة الدعوة، ويعود بمردود أكثر إيجابية على المدعوين.

والهدف من عرض هذه الصفات هو أن يراها القائمون على أمر الفتوى مـن منظور الدعوة، مما يدفع إلى استحضارها والتزامها، لتحقيق الدور الـدعوى المنشـود من خلال الفتوى، التي نأمل أن تكون سنداً للـدعوة والـدعاة في العصــر الحــاضر. وبيان هذه الصفات كالآتي: 


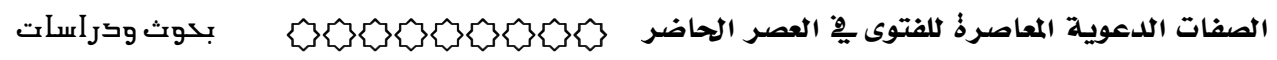

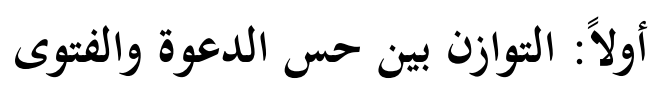

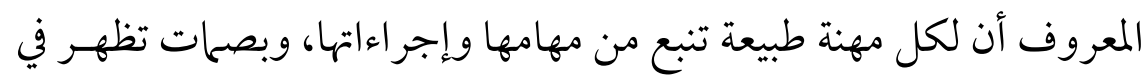

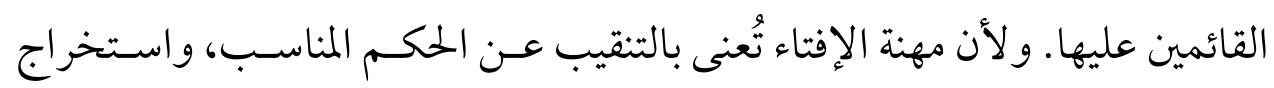

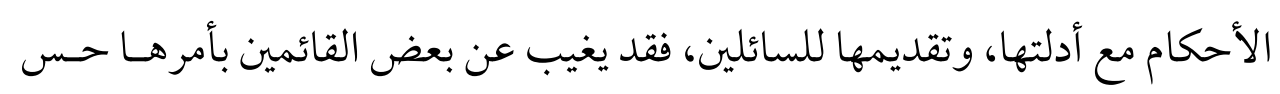

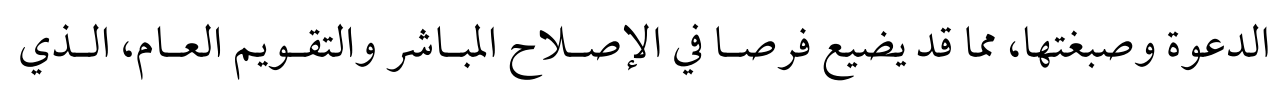
يسهل مهمة الدعوة؛ ويعين على الالتزام بمتطلباتها. والمقصود بحس الدعوة في إطار الفتوى ما يأتي:

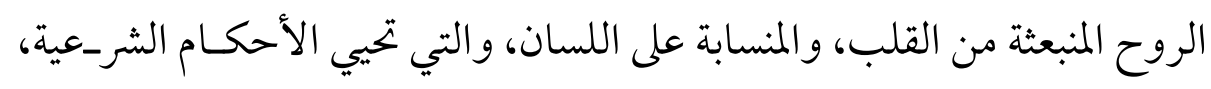

وتحيلها واقعاً ملموساً.

النظر إلى المستفتي على أنه مدعو، يحتاج إلى لين الجانب، ولطف القول، ومرونة

الفعل.

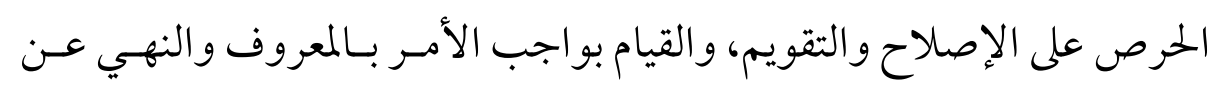

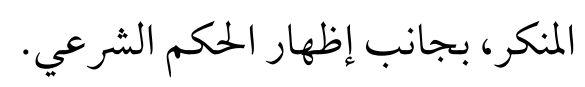

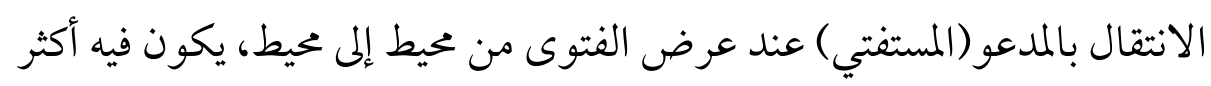

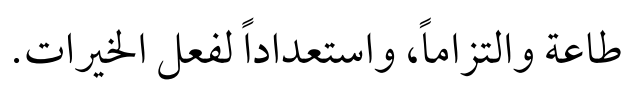

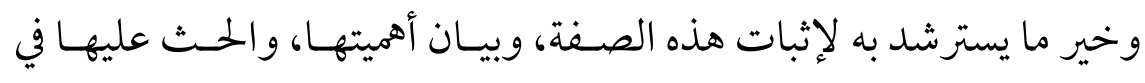

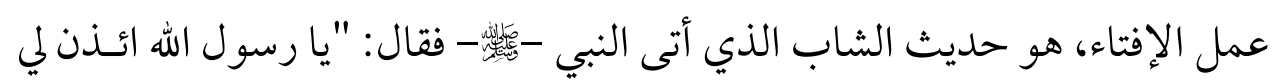

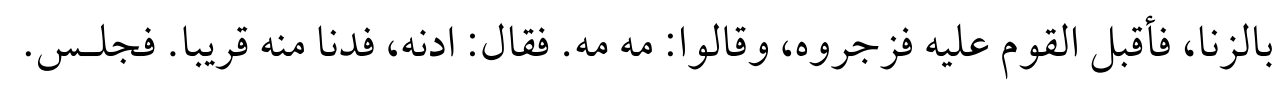

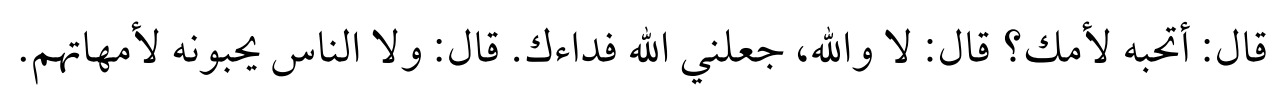

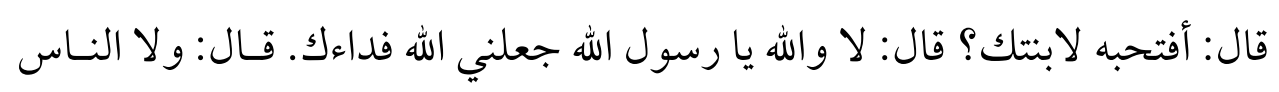

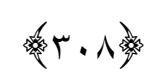


يجبونه لبناتهم. قال: أفتحبه لأختك؟ قال: لا والله جعلني الله فداءك. قال: ولا الناس

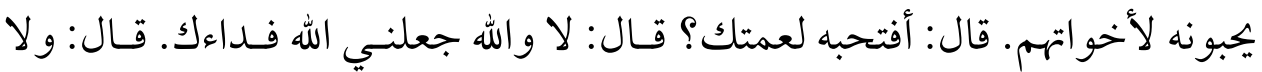
الناس يجبونه لعماتهم. قال: أفتحبه لخالتك؟ قال: لا واله جعلني الله فداءك. قال :ولا لال الناس يمبونه لخالاتهم. قال: فوضع يده عليه، وقال اللهم اغفــ ذنبـه، وطهـر قلبـه،

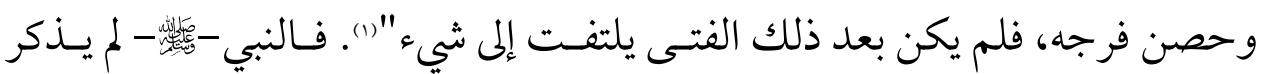

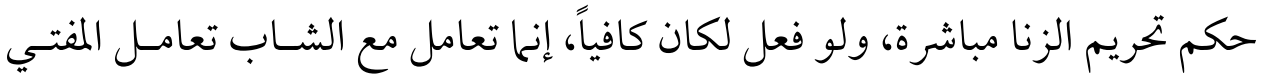

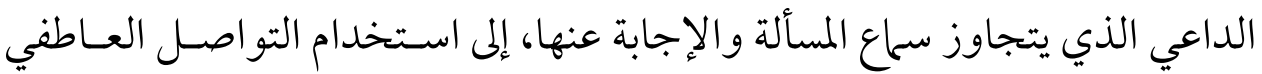

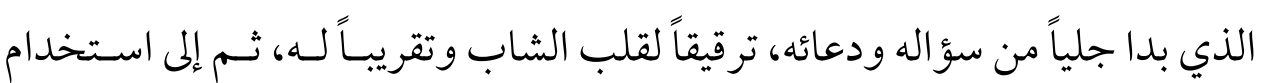

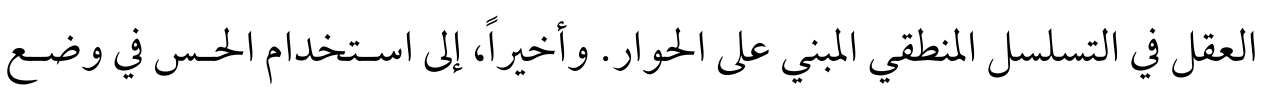

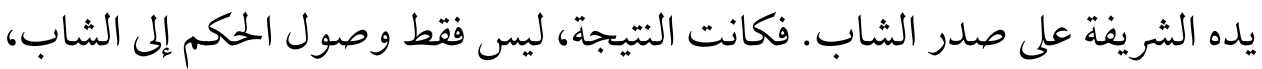
إنها الالتزام الفوري بالإقلاع الأبدي عن الحرام، فكان في ذلك صلاح دينه ودنياه. و المفتي -خاصة في العصر الحاضر - مطالب أن يستعين بهذه المنهجية النبوية،

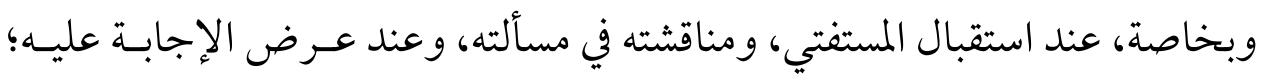
فذلك مما يساهم -ليس فقط - في تمهيد القلوب للسـاع والاستعداد للقبـول. وإنـا يقدم المفتي من خلال هذه المنهجية روح الإسلام ورحمته، وحرصـه وتقـديره لمنفعـة الإنسان.

ولاشك أن الفتوى الجافة في عباراتها، الغليظة في أسـلوبها، التسي لا تراعي

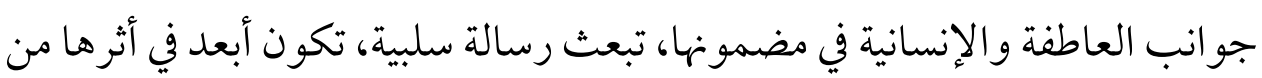

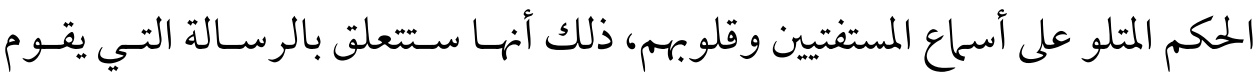

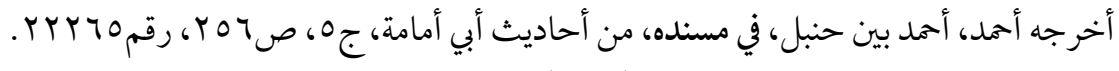




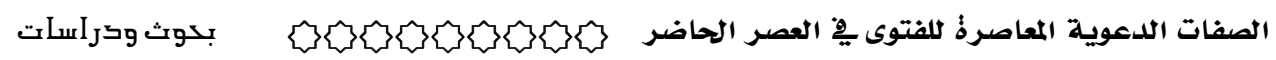
المفتي بتمثيلها في هذا المقام. فيقال أحيانا: ديسن متشـدد، ومفـت متعصسب، وحكــم جامد، مع أنه ربها ينطق بنفس الحكىم الذي نطق به غيره من المفتين ممن تحركو ابحسس سمس الدعوة، وصبغو ا فتو اهم بمناهجها. وبتحقق هذه الصفة يجمع المفتي بين من يقوم بصـنع الـدواء والمعالجـة مسن

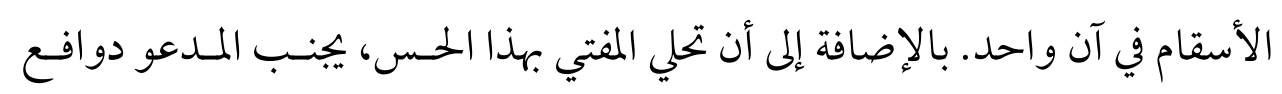

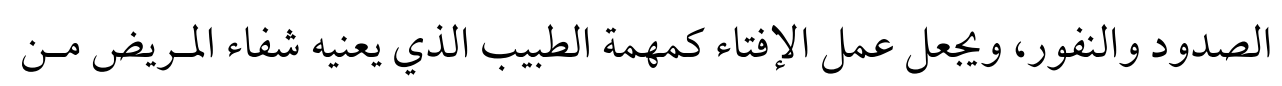
الداء، وليس -فقط - وصف الدواء. ثانياً: المؤسسية في صناعة الفتوى وهذه من الصفات التي يفرضها العصر الحاضر، الذي يقوم على المؤسسات و الهيئات في جُل شئونه. و أعني بمؤسسية الفتوى: اعتبارها صناعة عصرية، تُستخدم فيها التقنية الحديثة فيا يتعلق بالتو اصل والحصر والإحصاء، ويقوم بها المتخصصون المؤهلون بالعلم الشرعي وفق إجراءات معلومة وقواعد ضابطة، يُلتزم بها عندما تتوفر أسبابها، وتدعو الحاجة إليها، بهدف تيسير عملية الاتباع والمارسة لأحكام الدين ومتطلباته، مع مر اعاة الزمان و المكان.

فلا يقبل أن تكون الفتوى عشوائية، يقوم بها من ليس أهلاً لما، ومن لا يفهم ضو ابطها، و لا يراعي عصرها ومعاصريها، أو أن يشعر المستفيد منها أنها أقل خدمة مما يقدم في العصر من خدمـات متنوعة، من ناحية الإجراءات والتدوين والأداء. وغيرها من الأمور التي برز فيها العصر، وتنافست فيها الهيئات و المؤسسات. و لا شك أن تحلي الفتوى المعاصرة بهذه الصفة، يعد من أهم ما يلفت انتباه

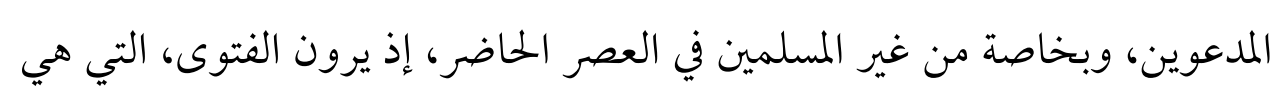


جزء أصيل من هذا الدين، تتحرك معهم في ظروفهم، وتُبنى على احتياجاتهم الواقعية، في حيوية وفاعلية، ونظام وانضباط؛ بهدف تحقيق التواصل الحي مع أتباع هذا الدين، وإعانتهم على تطبيقه بيسر في كل عصر.

ولتحقيق هذه الصفة على مستوى إصدار الفتوى المعاصرة، يجب أن يقوم المعنيون بالفتوى بإعداد المفتي المؤهل بآلات العصر بجانب العلم الشرعي، ولابد أن يكون الواجب الديني الزماني هو الدافع للقيام بالمهمة، وليس من أجل الارتقاء الوظيفي، أو الترف العقلي. فإذا دعت الحاجة، وتوفرت الأسباب، ووجدت الضرورة، لزم تعيين من يقوم بأمر الفتوى وإنتاجها من أهل التخصص، على أرقى ما يكون من مستويات الأداء العلمي والتقني. وأعتقد أن إقامة مؤسسات مركزية عالمية ومحلية للفتوى، وعقد المجامع الفقهية الدورية، عند النوازل والأحداث، يُعد خطوة عملية تجاه تقوية هذه المؤسسية في عملية استصدار الفتوى، ويجعل آثارها الدعوية أكثر انتشاراً، وإسهاماً في تحقيق رسالة الدعوة، وهداية الحيارى والباحثين عنها.

\section{ثالثاً: تنوع أساليب عرض الفتوى ووسائلها}

هناك تكامـل وتـازم أصسيل بـين الوسـائل والأسـاليب في عمليـة ممارســة

الدعوة، بمعنى أنـه إذا وجــدت الوسـيلة لزمهـا اختيـار أسـلوب العـرض والبيـان المناسب. وقد تكون الوسيلة صحيحة، ولكنها تفقد الأسلوب المناسب الـذي يحقـق هدف الرسالة الفكرية المحمولة عليها. ولذا وجدنا القرآن الكريم يـوصي بـالأمرين

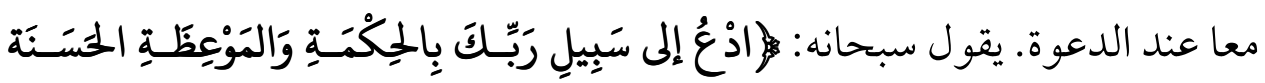

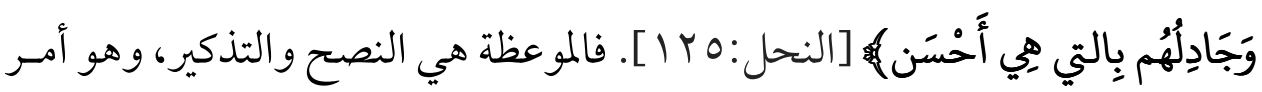
مالئم لطبيعة النفوس ور احتها، ولكن أسلوبها المطلوب، حتى تكون كذلك، هـو أن 


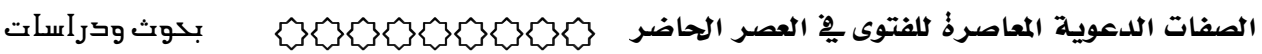
تكون حسنة، وإلا كان مردودها على النفس عكسـيا. و المجادلـة وسـيلة أخـرى مـن وسائل الدعوة، وأسلو.بها المطلوب أن تكون بالتي هي أحسن. و إلا أثـارت المجادلـة

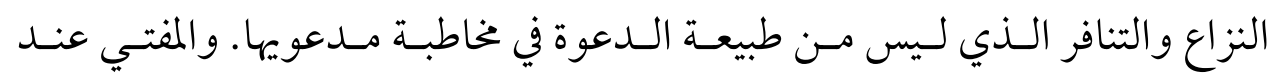
استصدار الفتوى و التعامل مع المستفتي، يحتاج أن يسلك مسلك الدعاة في اسـتخدام

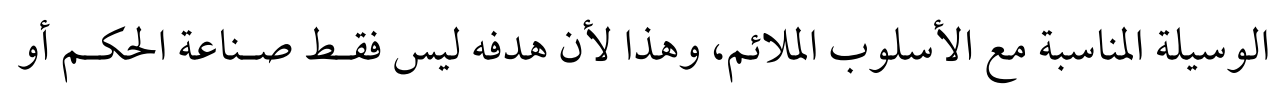
بيانه، إنها لابد أن يستعين بها يشرح الصدور، ويفتق العقول، ويعين على التنفيذ. ولهذا فهو مطالب أن يسلك إلى القلوب ما يصلحها، ويعمـل عـلى تفعيلهـا،

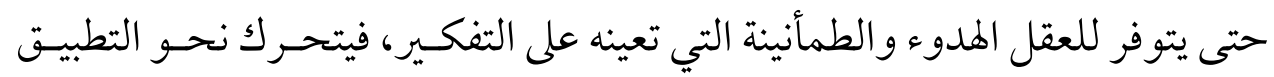

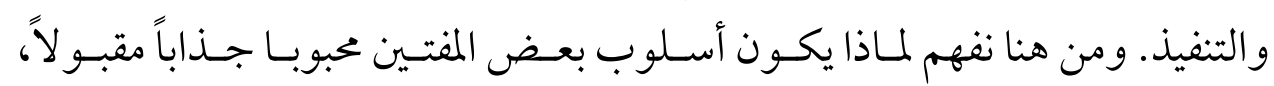
وبعضهم قد يكون منفر اً عند آخرين مع اتفاقهم في الإفتاء بنفس الحكم.

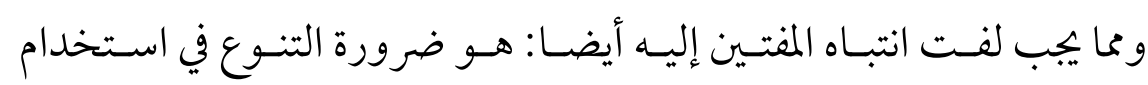
الوسائل والأساليب، ومناسبتها للو اقع والأفهام؛ بهدف الانسـجام مـع المسـتويات الفكرية وتوجهاتها عند المستفتيين، إذ أن ما يناسب البعض من وسائل قـد ينفـر منـه

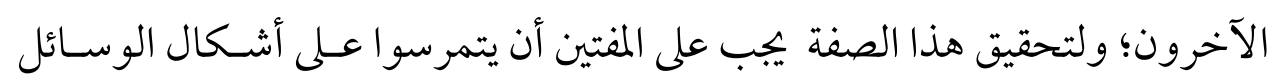
المتنوعة، وأن يتقنوا فن التنقل من وسيلة إلى أخرى، فذلك مما يعين على تحقيق الهدف الدعوي في الفتوى. وقد يبدو هذا الأمر صعباً، وبخاصة، مع الانشغال بأمر الفتوى، ولكن استحضار المفتي للحس الدعوي الذي أشرنا إليه سلفاً، يكسب المفتي قـدرة على تشكيل الوسيلة بشكل مباشر واختيار الأسلوب الأمثل لها.

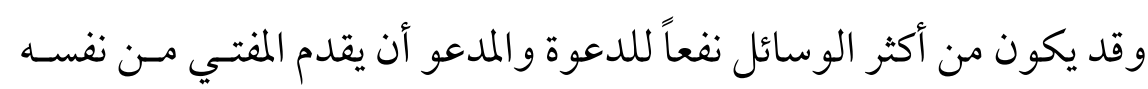
القدوة العملية والنمـوذج الحـي لمبـادئ الإسـالام وقيمـه. وبخاصـة، إذا كـان لقـاء المستفتي بالمفتي هو اللقاء الأول بعلماء الإسلام في المناصـب الدينيـة؛ وذلك لإرادة 


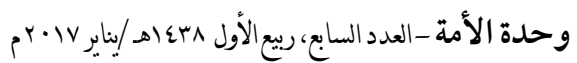

توبة نصوح من ذنب طال أمد وقوعه فيه، أو رغبة في عودة حميدة بعد طـول انقطساع

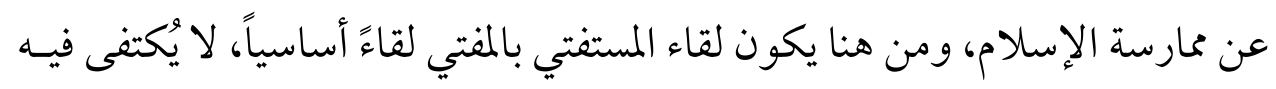

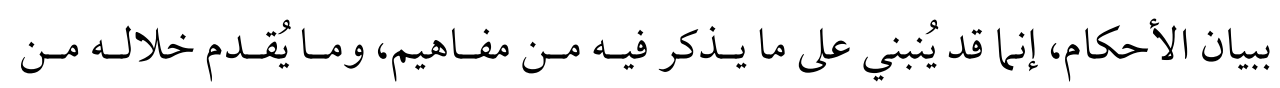

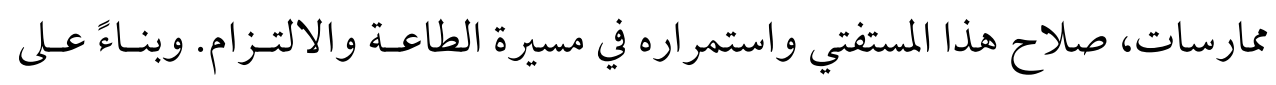
ذلك يلزم المفتي أن يتحلى بصفات الدعوة أكثر من الإفتاء، وأن يتعامل مع المستفتي كأنه مدعو أكثر من كونه باحثاً عن إجابة لسؤال. وترجمة خصائص الإسلام و صفاته

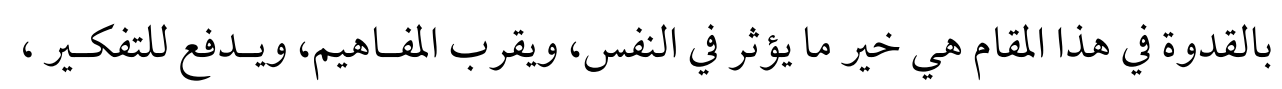
ويثير الفضول لطلب المزيد.

\section{رابعاً: الإحاطة بظروف الزمان وطبيعة المكان}

إحاطة القائمين على الفتوى بعلم السابقين، ووقوفهم على أحكام التنزيل من

المصادر والأصول، لا يفصلهم أبداً عن الزمان والمكان الذي تصنع فيه الفتـوى، إنها

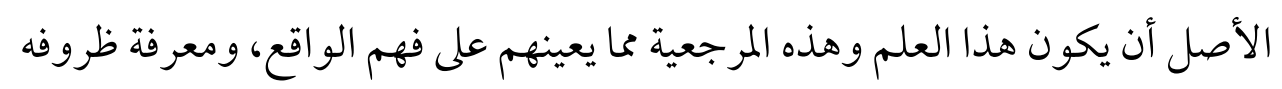
و أحو ال قومه. فذلك مما يعين على إصدار الفتوى الواقعية القابلة للتطبيق، المسـاعدة

$$
\text { على الالتزام و الاقتراب من الدين. }
$$

ومما يضر بالدعوة -في كثير من الأحيان- أن يكون حسال المفتـي هـو النقـل

و الاقتباس من كتـب السـابقين، و التشـدد في إلـز ام النـاس بهـا، بـدعوى الاحـترام و التقدير لمن سبق، و اتهام النفس بعدم بلوغ فضلههم؛ فتنقلب الأمور إلى أن تكون فتنة

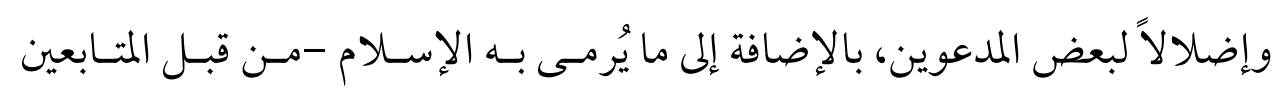
الحاقدين - بأنه رجعي متخلف.

ويرى الباحث أن هذا المسلك المتجمد حول القديم في أمور الفتوى مرفوض دعوياً، لما سبق ذكره، وأيضا لما نقله علماء الإسلام ممن استشعر أهميـة ارتبـاط المفتسي 


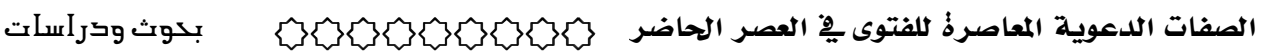
بزمانه ومكانه. من ذلك ما ذكره القرافي خخاطباً المفتين بقوله:"فمها تجدد في العـرف،

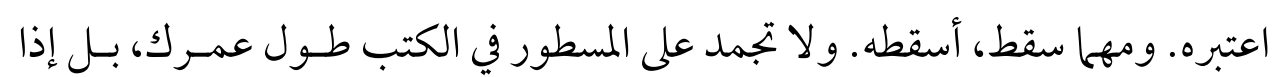
جاءك رجل من غير أهل إقليمك يستفتيك، لا تجره على عـرف بـــك، واسـأله عـن عرف بلده، وأجره عليه، و أفته به دون عرف بلدك والمقرر في كتبك، فهـذا هـو الحـق

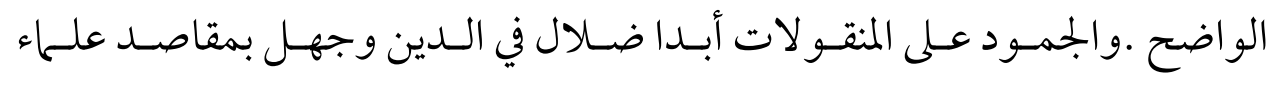
المسلمين و السلف الماضين" (1). ويذكر القرضاوي: أن الجمود على الفتاوى القديمـة، دون مراعاة لظروف الزمان والمكـان، و العـرف والحـال يعـد مـن مزالـق المتصـدين للفتوى في العصر الحاضر. (r) ومن أهم ما يجب أن ير اعيه المفتون في معرفـة الزمـان والمـــــان هـو مـا كـان متعلقاً بالأماكن التي يعيش فيها المسلمون أقلية، تحت حكم أغلبيـة تختلـف قو انينهـا وتقاليدها وثقافتها عحا يدين به المسلمون. وهذه الأقلية مطالبة -بدءاً - أن يكون من بين أفرادهـا مـن يقـوم بمسـؤولية

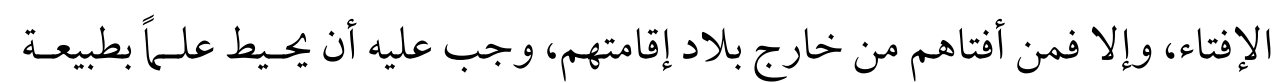
البيئة التي يعيشون فيها من الناحية السياسية والاجتماعية والثقافية و القانونية، فذلك أدعى أن تكون فتواه واقعية عملية، تحقق العون والسـند المرجـو للأقليـات المسـلمة

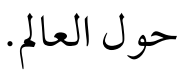
خامساً: الإلمام بأحوال وظروف المستفتي وهذه الصفة مترتبة على ما سبق من صفات، فالحس الدعوي هو الذي يدفع

$$
\begin{aligned}
& \text { أبو العباس أحمد القر افي، أنوار البروق في أنواء الفــروق، تحقيـق: خليـل المنصـور، ( بـيروت، دار }
\end{aligned}
$$

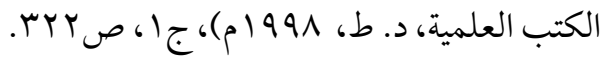

$$
\begin{aligned}
& \text { يوسف القرضاوي، الفتوى بين التسيب والانضباط، ص •9. }
\end{aligned}
$$

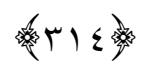


المفتي أن يقضي وقتاً لمعرفة أحو ال مستفتيه، العامة والخاصـة، الشخصـية و العائليـة، الدينية والسلوكية، فهو لا يتعامل مع سؤ ال مكون من ألفاظ وعبـارات جامـدة، ولا يعتمد على المشافهة أو الكتابة فحسب، إنحا ينظر للمستفتي على أنه فرد يتمتـع بقلـب وعقل، وله ذاتيته وظروفه التي جاء الشرع ليصبغها بصبغة الإسـالام، ويجفظهـا مـن الذوبان. ولذذا لابد أن يمهد المفتي لنفسه قبل إصدار الفتوى بهذه المعرفة الضـرورية عن المستفتي (المدعو) ويمكن أن يكون ذلك بأحد الطرق الآتية: جلسة تعريفية تمهيدية مع المستفتي، يستخدم المفتي فيها فراسته من خلال الحوار و النقاش.

استبانة تعريفية مكتوبة، يقدمها المستفتي عند عرضه للسؤال. تعيين أحد المعاونين المتميزين لإجراء محاورة مع المستفتي، وتقديم تلخيصها للمفتي، وذلك للمساهمة في حفظ أوقات المفتي.

ولاشك أن هذه المعرفة بأحوال المستفتي، تعين المفتي على صناعة الفتوى المناسبة، كما تمكنه من القيام بواجب الدعوة فيما عساه أن يعرفه من أمور تحتاج إلى توجيه أو إرشاد، أو إصلاح وتقويم، كحا أنها تفيد في معرفة مفتاح الشخصية؛ بها يساعد على اختيار وسيلة البيان والإخبار بها يعين المستفتي على الالتزام. وممن يقتدى بهم في ذلك ابن عباس رضي الله عنه. فقد كان يقول: "لمن قتل مؤمنا توبة"، فجاءه رجل فسأله، ألمن قتل مؤمنا توبة؟ قال: لا، إلا النار. فلم) قام الرجل. قال له جلساؤه: ما كنت هكذا تفتينا، كنت تفتينا، أن لمن قتل مؤمنا توبة مقبولة، فما شأن هذا اليوم؟ قال: إني أظنه رجل يغضب، يريد أن يقتل مؤمنا، فبعثو افي أثره، فوجدوه كذلك" (1).

جلال الدين السيوطي، الدر المثثور في التفسير بالمـأثور، (بـيروت: دار الفكـر، د. ط، سو99 م)، 


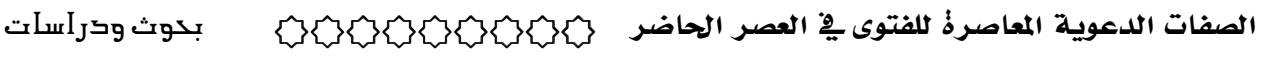
فهذه هي الفراسة التي تجعل المفتي داعية حريصا، لا يلقي الإحكام إلقاء نظرياً، إنما

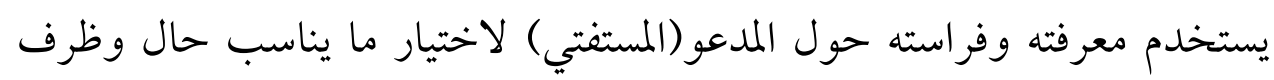
السائل، حتى ولو خالف في ذلك مذهبه. ويدخل في معرفة أحو ال المستفتي: تاريخ إسلامه، ومستوى ماهبه، التزامه، ومقدار

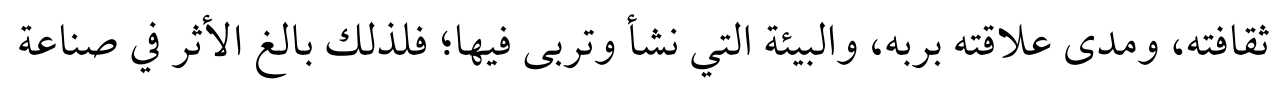
الفتوى، وتغيرها من حال إلى حال، وبخاصة، مع المسلمين الجدد في بلاد غير المسلمين. سادساً: الصناعة العملية القابلة للثطبيق

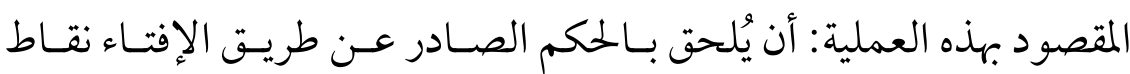

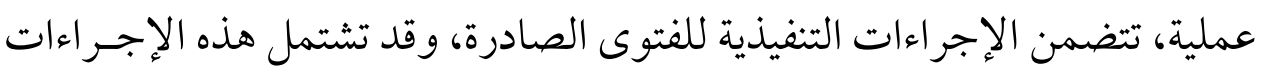

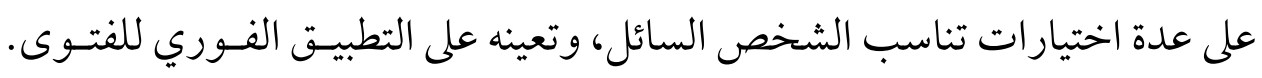

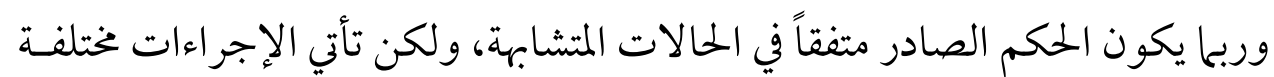

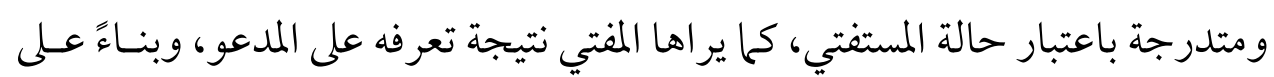
حاسته الدعوية.

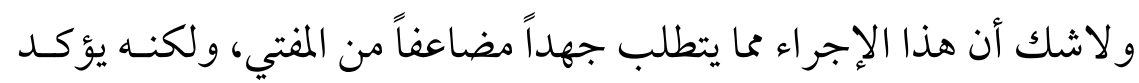

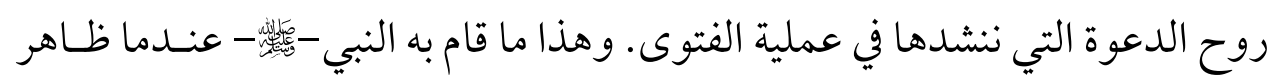

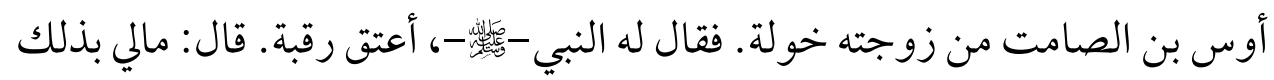

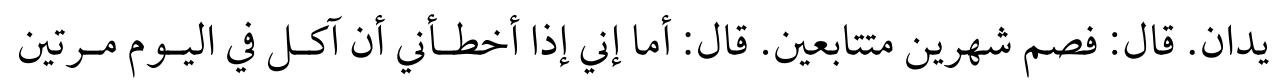

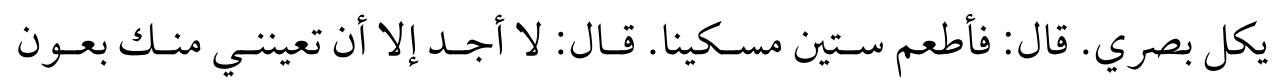

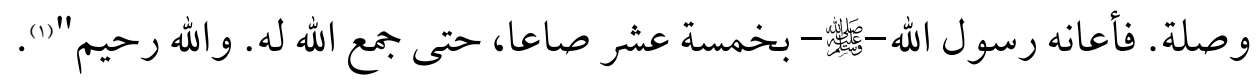

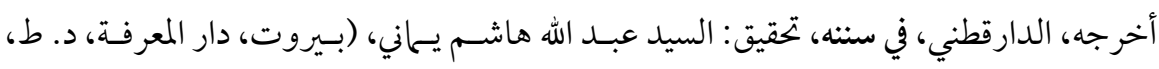

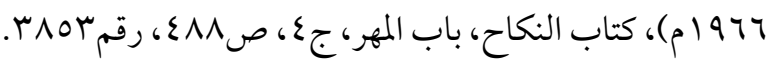




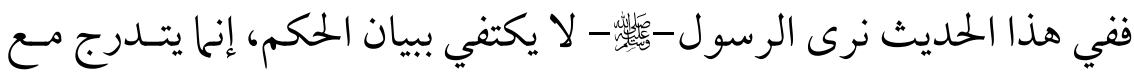
السائل في بيان إجر اءات عملية التنفيذ للحكم، حتى وصل معه إلى ما يناسب حالته. وظروفه، ثم أعانه على القيام بالحكم.

وهكذا، يستطيع المفتي أن يؤدي دوره الدعوي من خلال فتو اه التي يقـدمها للمستفتي، في حرص شديد على أن يطبق السائل حكم الله ويلتزم به. ومما يؤسف لـه في بعض الفتاوى المعاصرة افتقادها لجانب العملية والتطبيق، يظهر ذلك من الصـور الآتية:

تكرار عرض الفتوى نصاً ومضموناً بمجرد أن يكون السؤال متشابهاً؛ بمعنى لهو العودة إلى الأرشيف وتكرار طباعة الفتوى دون النظر إلى حال المستفتي وقدراته و إمكاناته في عملية التطبيق. إحالة المستفتي إلى فتاوى سابقة، وتركه يتخير منها. استخدام لغة موحدة في الأسلوب والعبارات، دون الالتفات إلى خخاطبة الناس على قدر عقولمم. حشو كثير من الفتاوى بالآراء المتعددة، دون الإشارة إلى المختار والأنسب منها،

$$
\text { بل يترك الاختيار للمستفتي في كثير من الأحيان. }
$$
خلو كثير من الفتاوى من إجراءات عملية تعين المستفتي على التطبيق.

\section{سابعاً: التنسيق والتكامل بين الدعوة والإفتاء}

مهمة الدعاة تقتضي احتكاكاً مباشراً مع المدعوين، ومعايشة قريبـة لهم عـلى

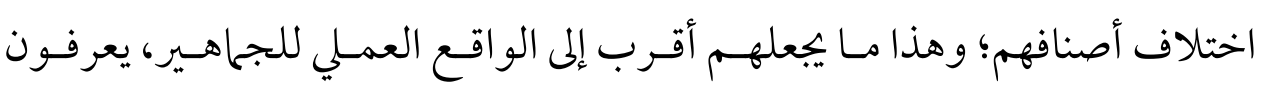
مشاكلهم، ويشعرون بآلامهم، ويرقبون نبضهم، ويشار كونهم أفـر احهم وأتـر احهم. 


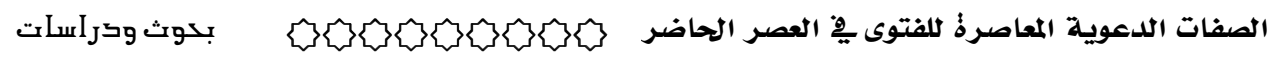
أما المفتي فطبيعة مهمته قد لا تتيح له مثل هذا النوع من التو اصل. و ومن هنـا جـاءت أهمية التنسيق و التكامل بين الإفتاء والدعوة لصالح المدعو.

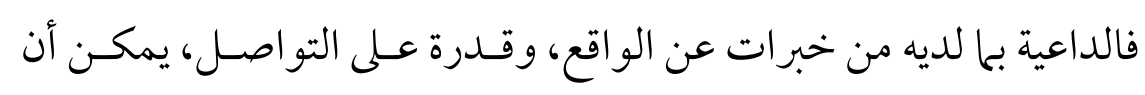
يكون سنداً بين يدي المفتي ليعينه على استنباط الحكم السليم القابل للتطبيق.

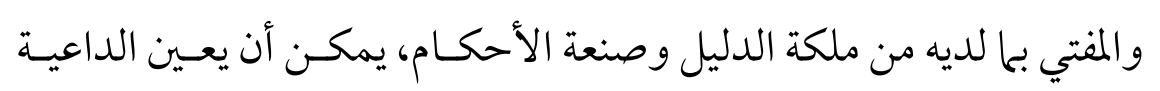

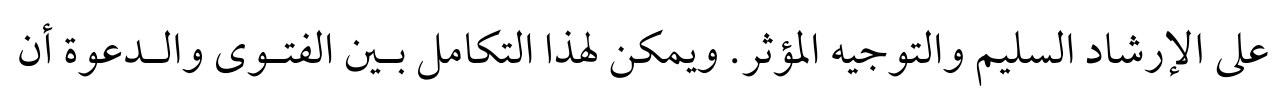

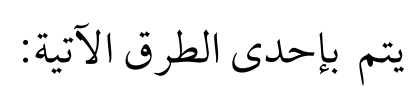
أن يكون هناك أعضاء من تخصص الدعوة، يشاركون في لجان الفتوى بشكل دائم، وبخاصة في الفتاوى العامة عند النوازل والمستجدات. أن تعرض الفتوى قبل إعلانها على مجموعة من الدعاة بهدف المشورة، والوصول إلى اتفاق حول آلية البيان والإخبار، ومناسبة ما يقال على المستفيدين من الجمهور أن يجتمع المفتون مع بعض الدعاة من أجل توحيد توصيف الوقائع والنوازل التي تحتاج إلى سبق في الإفتاء. ضرورة أخذ آراء الدعاة عند تقييم ومراجعة الفتاوى بعد صدورها وتعميمها،

$$
\text { بهدف تجديدها و تطويرها ما أمكن. }
$$

ولقد رأينا في غزوة بدر(1)كيف استشار النبيالمؤيد بالوحي أبا بكر وعمر، وهما أهل الخبرة والدراية بالواقع والعادات والتقاليد،

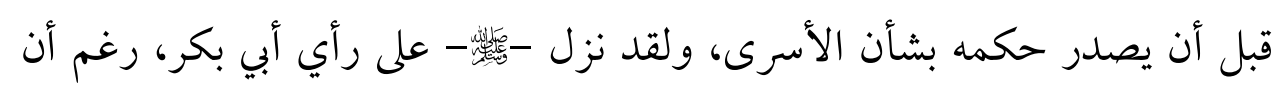

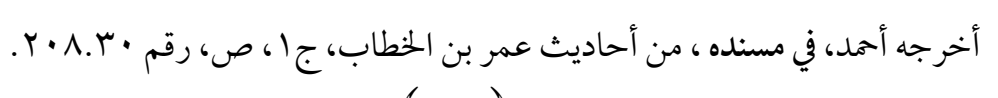




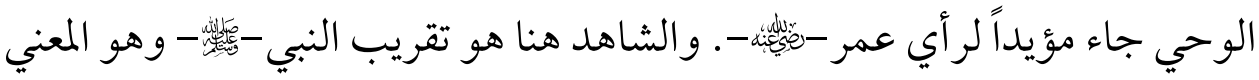
بإصدار الحكمى - من يستشيرهم، برغم أنه هو المصدر والمرجع في بيان الحكم، ليبين أن تواصل وتكامل الخبرات قبل إصدار الأحكام يعتبر من حكمة المرسلين، التي يجب أن يتبعهم فيها ورّاثهم من أهل الدين. و أعتقد أن تحقق هذا النوع من التواصل بين رجال الدعوة والإفتاء فوق ما يضفيه من احترام وتقدير للتخصصية في الدين، هو كذلك يقلل من نسبة الخطأ في فهم وتطبيق الفتاوى بين شريحة المستفتين من المدعوين، ويعمل على تحقيق كثير من الصفات التي سبق الإشارة إليها. ثامناً: جاهزية الفتوى ومبادرتها عند النوازل والأحداث وهو ما يمكن أن يوصف بالإيجابية في صناعة الفتـوى، ذلك أن الغالـب في أمر الفتوى، أن تكون إجابة عن سؤال يرفعه المستفتي لمفتٍ معين في قضية خاصة، أو

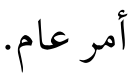
أما ما نقصده هنا: فهي الحركة الذاتية التي تنبع من المسئولية الشـــرعية عنــــ المفتي أو المؤسسات المعنية؛ فتدفع إلى بيـان الأحكـام، وإرشـاد النـاس، دون انتظـار سائل، بل يعد المفتي نفسه قائحاً مقام المستفتي، أو أن يجعل النازلة أو الحــدث في مقـام المستفتي، فيبادر إلى الهداية والبيان قبل ظهور الجهال وإشاعة الضلال. ونزول النازلة، أو وجود الحدث الذي يحتاج إلى بيان حكم الشرع، يجعل هذه المبادأة بالإجابة واجبـة في حق أهل الفتوى، تماماً ،كا لو سأل سائل. وقيـام المفتـي بهـذا الواجـبـ، وتحليـه بصـفة الإيجابيـة والجهوزيـة في بيـان الأحكام، يجعله يشترك مع الداعية في واجب البدء بالبلاغ، والتعريف العام بالإسلام دون سؤال أو ابتداء من المدعو. 


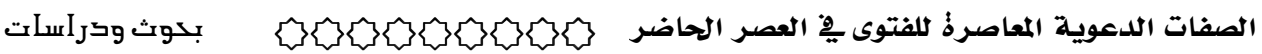

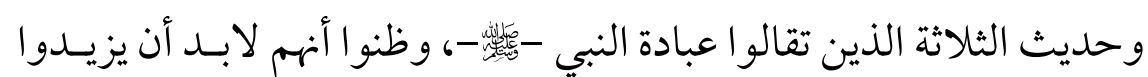

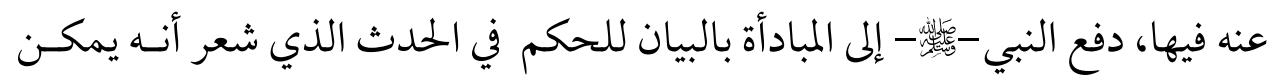
أن يصبح ظاهرة عامة، وذلك قبل أن يستشري أمره. فالقصة تشير إلى أن الأمر تعدى الو احد و الاثنين إلى الثلاثة، والسكوت عنه -في حال معرفته ومعاصرته- يعد اعتماداً

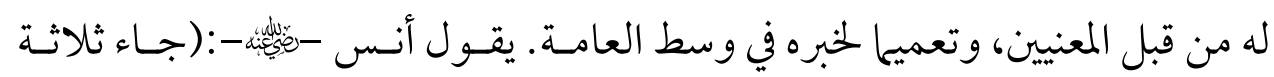

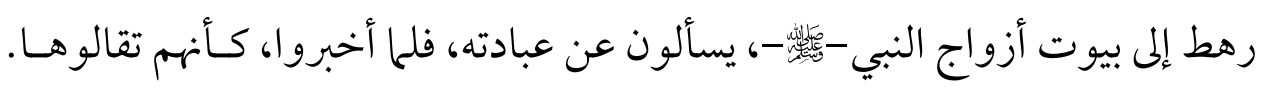
فقالو ا: أين نحن من النبي أحدهم: أما أنا فإني أصلي الليل أبدا. وقال آخر: أنا أصـوم الـدهر ولا أفطـر. وقـال

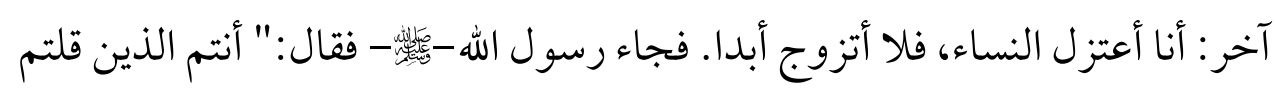
كذا و كذا؟ أما و الله إني لأخشاكم الله وأتقاكم له، لكني أصوم و أفطر، و أصلي وأرقـد، و أتزوج النساء، فمن رغب عن سنتي فليس مني "(1).

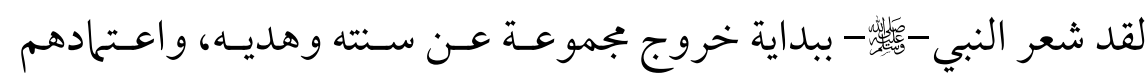

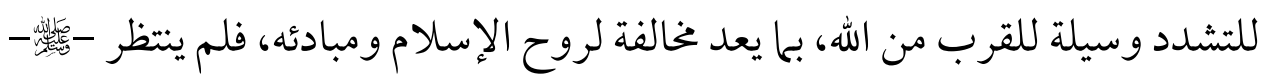
ليرى اتساع الأمر في أمته، أو حتى يرى النتائج المتوقعة مـن قـرار المتقـالّين لعبادتـه، المشددين على أنفسهم، إنها جمعهم وغَيْرهم، وبدأ يعلن حكم الشرع فيهم، وفي ذلك تك

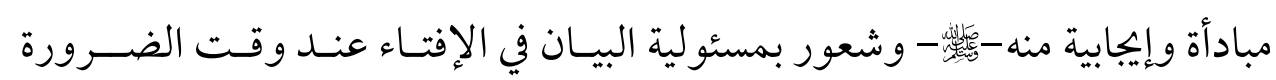
و الحاجة. وهذا ما نأمل أن يقوم بـه المفتـون في العصــر الحـاضر الـذي كثـرت فيهـا

أخرجه البخاري، في صحيحه، تحقيق وتعليق: مصطفى البغا، (بـيروت، دار ابـن كثـير، اليمامـة،

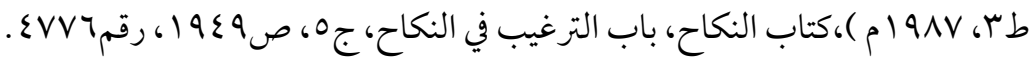
蓶r. 


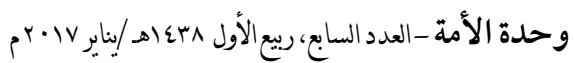

الظو اهر والأحداث وتنوعت، ولربها لو عولجت عند بداية ظهورهـا، وسـارع أهـل الفتوى بأخذ موقف حاسم في أمرها، بإظهـار حكــم الله فيهـا، مـا كانـت المفاجـآت والأهو ال التي قد تدفع لعجلة أو لمصلحة ما، إلى التسـرع والجر أة على أحكام الله من غير العلماء و المتخصصين. فتقع الدعوة في أزمات داخلية عنيفـة، تـؤثر عسلى تحركهـا و القيام بو اجباتها، فوق أنه مضيعة للأوقات وتفتيت للجهود، وربها لو عـولج الأمـر باكراً مع ظهوره، لكُفيت الدعوة عـبـ الانشـغال بـه، ولسـلمت مـن غبـار آثـاره، وتفرغت لأمر دعوي أكثر إيجابية وبناءً.

و.بهذه الصفة يصل الباحث إلى ختام هذه الدراسة التي لا يزعم أنها أحصت أحته

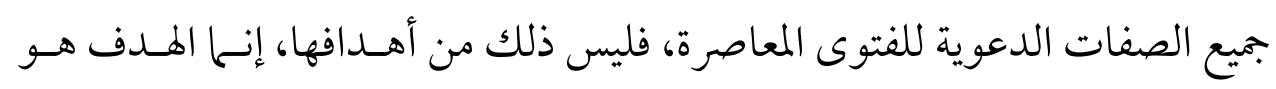
تأكيد الرابطة الوثيقة بين الدعوة والفتوى، وبيان أثـر ذلـك عـلى الـدعوة المعـاصرة،

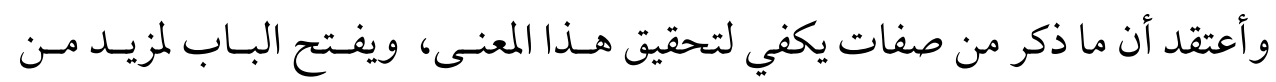
الدراسات والموضوعات التي تدعم مثل هذه الأبحاث البينيـة في محيط الدراسـات الشرعية في العصر الحاضر.

\section{الخاتمن}

\section{أهم النتائج والتوصيات}

أولاً: النتائج

الدعوة والفتوى من أدوات هذا الدين الثابت في أصوله ومبادئه، والمتغير المرن في

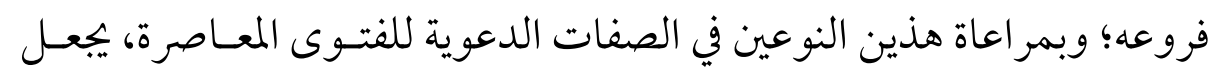

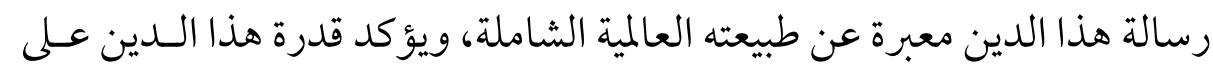
استيعاب قضايا العصر و التعامل معها. 乘似 


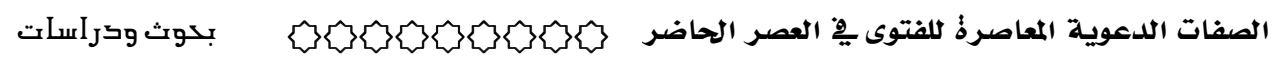

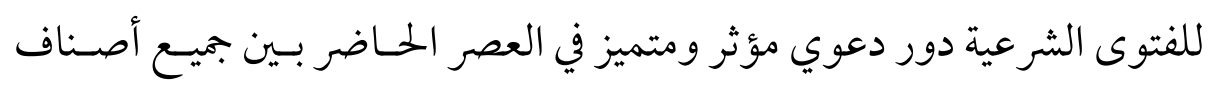

المدعوين، المسلم وغير المسلم، وذلك عن طريق تقوية مفاهيم الـدعوة و أصـولها في قلوب الأتباع، وإزالة الشبهات والاضطر ابات الفكريسة مـن قلـوب المرتـابين و المتشككين.

الفتوى في صياغتها وعرضها، إما أن تؤكد صدق الرسالة، فتكون بذلك وسـيلة فاعلة من وسائل الدعوة المعاصرة، أو تكون بعيدة عن مراعـاة الواقـع ومعالجـة قضاياه، فتكون سببا في إثارة الشبهات وتوسيع الهـوة، مــا يصـعب المهمــة عـلى

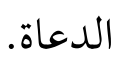

يستطيع المفتي أن يقدم الرسالة الإيجابية العصرية للإسلام، في مصدرها الربـاني، و منهجها الشامل، وتوازنها الإيجابي، عند فهمه للواقع وإدر اكه لظروف و أحو ال المستفتين. الأقليات المسلمة مطالبة أن يكون من بين أفر ادها من يقـوم بمسـؤولية الإفتـاء، وإلا فو اجب المفتي من خارج بلادهم، أن يجيط علماً بطبيعة البيئة التسي يعيشـون فيها، من الناحية السياسية والاجتهاعيـة والثقافيـة و القانونيـة، فـذلك أدعـى أن تكون فتو اه واقعية عملية، تحقق العون والسند المرجو للأقليـات المسـلمة حـول

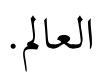
الأبحاث البينية بين فروع العلوم الشرعية والدراسات الإسلامية، باتت ملحـة، خاصة في العصر الحاضر، لخدمة أهداف الإسلام العظمى، ولحسن تمثيل علومسه بين التخصصات الأكاديمية المختلفة. 
ضرورة التواصل المستمر، والتنسيق الدائم بين رجال الدعوة والإفتاء، فذلك مما يقلل من نسبة الخطأ في فهم وتطبيق الفتاوى بين شريحة المستفتيين من المـدعوين، كما يعين على صناعة الفتوى الشرعية الواقعية المتوازنة. ضرورة تبني الفتوى المعاصرة لأهداف الدعوة في تحقيـق هـدف الإسـالام العـام نحو هداية البشرية للتعرف عـلى الخـالق، وذلـك عـن طريـق الإرشـاد والبيـان و التربية على تعاليم الإسلام. ضرورة أن يستحضر المفتي دائما حاسة الداعية بجانب حاسة الإفتاء، وذلك عند صناعة الفتوى، وعند تعامله مع المستفتي.

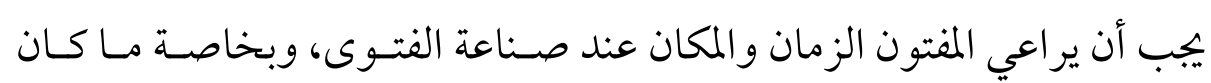

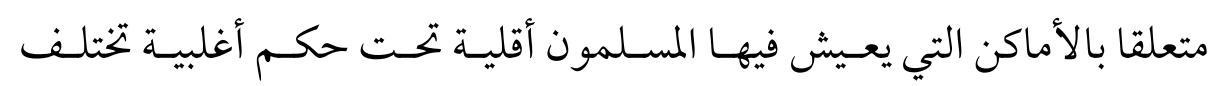
قو انينها وتقاليدها وثقافتها عحا يدين به المسلمون. ضرورة التنسيق والعمل المشترك بين مؤسسات الدعوة وهيئات الإفتـاء خاصسة فيما يتعلق بصناعة الفتوى المتعلقة بالنوازل والأحداث المعاصرة.

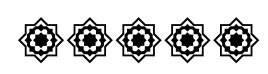

